\title{
1 scRNA-Sequencing uncovers a TCF-4-dependent transcription \\ 2 factor network regulating commissure development
}

Marie-Theres Wittmann, ${ }^{1}$ Philipp Kirchner, ${ }^{1}$ Arif B. Ekici, ${ }^{1}$ Elisabeth Sock, $^{2}$ D. Chichung Lie, ${ }^{2,3}$ André Reis ${ }^{1,3}$ *

${ }^{1}$ Institute of Human Genetics, Universitätsklinikum Erlangen, Friedrich-Alexander-

Universität Erlangen-Nürnberg (FAU), Erlangen, 91054, Germany

${ }^{2}$ Institute of Biochemistry, Emil Fischer Center, Friedrich-Alexander-Universität Erlangen-Nürnberg, 91054, Germany

3 These authors contributed equally to this work

* Correspondence: andre.reis@uk-erlangen.de

* Corresponding author:

Prof. Dr. André Reis

Institute of Human Genetics

Universitätklinikum Erlangen

Friedrich-Alexander-Universität Erlangen-Nürnberg

91054 Erlangen

Germany

E-mail: andre.reis@uk-erlangen.de

Running title: Transcription factor 4 in forebrain development

Abstract

Text body

References

Figures

Supplemental tables 


\section{Abstract}

4 Intercortical connectivity is important for higher cognitive brain functions by providing 5 the basis for integrating information from both hemispheres. We show that ablation of 6 the neurodevelopmental disorder associated bHLH factor Tcf4 results in complete 7 loss of forebrain commissural systems in mice. Applying a new bioinformatic strategy 8 integrating transcription factor expression levels and regulon activities from single cell

9 RNA-sequencing data predicted a TCF-4 interacting transcription factor network in 10 intercortical projection neurons regulating commissure formation. This network 11 comprises a number of regulators previously linked to the pathogenesis of intellectual 12 disability, autism-spectrum disorders and schizophrenia, e.g. Foxg1, Sox11 and 13 Brg1. Furthermore, we demonstrate that TCF-4 and SOX11 biochemically interact 14 and cooperatively control commissure formation in vivo, and regulate the 15 transcription of genes implied in this process. Our study provides a regulatory 16 transcriptional network for the development of interhemispheric connectivity with 17 potential pathophysiological relevance in neurodevelopmental disorders. 
Introduction

21 Cognitive abilities are highly dependent on the establishment of proper neuronal connectivity between different brain regions and its cellular components (Constantinidis and Klingberg 2016; Hedden and Gabrieli 2004). The corpus callosum, the anterior commissure, and the hippocampal commissure, carry axons across the midline and ensure information flow and coordination between the cerebral hemispheres. Of these, the corpus callosum (CC) is the largest commissural tract of the human brain (Tomasch 1954). Callosal connections serve to integrate and coordinate of sensory-motor functions from the right and left side of the body and are integral to high-level cognitive functions including language, abstract reasoning and high-level associative function (Paul et al. 2007).

Mutations in a number of factors controlling developmental processes such as neuronal precursor proliferation, fate specification, migration and axon guidance, are associated with structural anomalies of commissures (Edwards et al. 2014; Lindwall et al. 2007; Paul et al. 2007; Richards et al. 2004), illustrating that commissure development is highly dependent on the expression of complex genetic programs. Orchestration of the precise temporo-spatial execution of developmental programs is most likely achieved by cell-type specific combinatorial activity of transcription factors. However, information on the composition of transcription factor networks in commissural development remains scarce and is largely confined to the regulation of upper layer neuron specification, which is highly reliant on a SATB2-dependent genetic network (Alcamo et al. 2008; Britanova et al. 2008). The class I basic helix-loop-helix (bHLH) transcription factor (TF) TCF-4 (transcription factor 4) has recently emerged as a critical transcriptional regulator in forebrain development. Variants in TCF4 have been associated with schizophrenia, autism and intellectual disability and TCF4 haploinsufficiency causes the neurodevelopmental disorder Pitt-Hopkins syndrome (PTHS) (OMIM 610954) (Amiel et al. 2007; De Rubeis et al. 2014; Navarrete et al. 2013; Schizophrenia Psychiatric Genome-Wide Association Study 2011; Schizophrenia Working Group of the Psychiatric Genomics 2014; Stefansson et al. 2009; Steinberg et al. 2011; Zweier et al. 2007).

Alterations of TCF-4 dosage in mice lead to disruptions in neocortical neuronal

51 migration, specification of neuronal subtypes, dendrite and synapse formation (Li et al. 2019; Page et al. 2017). Most notably, TCF4 haploinsufficiency in human and 
53 mice is associated with callosal dysgenesis indicating that Tcf4 is part of a conserved

54 genetic network controlling the formation of callosal connections (Jung et al. 2018).

55 TCF-4 belongs to the class I basic basic Helix-Loop-Helix (bHLH) transcription factor family and its transcriptional output is highly dependent on its interaction partners. Traditionally, it is assumed that TCF-4 executes its function through dimerization with proneural class II bHLH TFs (Bertrand et al. 2002; Massari and Murre 2000). A recent in vitro study, however, proposed that TCF-4 may be able to interact with a variety of transcriptional regulators outside of the traditional interaction partners of the bHLH class (Moen et al. 2017). TCF-4-interacting transcription factors in the regulation of interhemispheric connectivity have not been identified. Such identification is hampered by the technical challenges to perform unbiased in vivo interactome analyses in a cell type specific manner. Here, we generated homozygote Tcf4 knockout (Tcf4KO) mice to further validate the role of TCF-4 in the establishment of interhemispheric connectivity. We report that loss of Tcf4 results in the complete agenesis of forebrain commissures. Using singlecell RNA sequencing (scRNA-seq) followed by the integration of transcription factor expression levels and regulon activities we uncover a TCF-4 interacting transcription factor network for commissure development in Satb2 expressing neurons. Surprisingly, this transcription factor network involves numerous transcription factors outside the bHLH class. Similar to TCF-4, these interactors are often associated to neurodevelopmental disorders such as intellectual disability, autism and schizophrenia. Further analysis of the interaction between TCF-4 and the regulator SOX11 uncovered a synergistic effect on anterior commissure (AC) and CC formation. Collectively, our findings provide insight into a novel gene regulatory network controlling commissure formation and potentially involved as a common pathogenic pathway in neurodevelopmental and neuropsychiatric diseases.

\section{Results}

\section{Tcf4 knockout abolishes commissure development}

Tcf4 haploinsufficient mice generated by an insertion of a lacZ/neomycin cassette before exon 4 (Figure 1A) show dysgenesis of the corpus callosum (Jung et al. 2018). To further examine the critical role of Tcf4 in development of interhemispheric connectivity, we generated Tcf4 homozygote knockout mice. Effectiveness of the 
Tcf4 knockout was assessed by western blot as there are Tcf4 isoforms with transcriptional start sites after exon 4 (Sepp et al. 2011). Our analysis confirmed the loss of the longest TCF-4 isoform (TCF-4B) in the knockout; expression of a shorter isoform (TCF-4A) persisted (Figure 1B). Despite the residual TCF-4 expression, Tcf4KO mice died shortly after birth, indicating the importance of the long TCF-4 isoform during development.

The most striking feature of PO KO brains was the absence of the forebrain commissure system, i.e. CC, AC, and hippocampal commissure (Figure 1C, D). Staining for the upper layer and interhemispheric projection neuron marker SATB2 (Alcamo et al. 2008; Britanova et al. 2008) revealed a significant increase in SATB2 positive neurons (SATB2+ cells/800 $\mu \mathrm{m}$ VZ: WT $1146 \pm 75.89$; KO $1389 \pm 92.45 ; \mathrm{p}=$ 0.0079), which appeared to be generated at the expense of CTIP2 (CTIP2+ $/ 800 \mu \mathrm{m}$ VZ: WT $691 \pm 64.2$; KO $476 \pm 33.9 ; p=0.0079$ ) but not of TBR1 positive deep layer

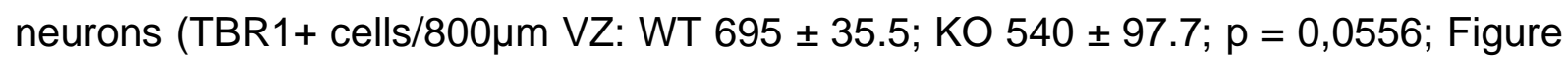
$1 \mathrm{E})$. These data indicate that the commissure forming SATB2+ neurons were in principle generated in Tcf4KO mice. Analysis with the anterograde lipohilic tracer Dil indicated that neurons in Tcf4KO mice extended their axons towards the midline yet were unable to cross to the contralateral side (Figure 1D). Staining for GAP43, a marker for the axonal growth cone verified this observation (Figure 1F).

Callosal agenesis can be the consequence of dysfunctional midline generation and fusion (Richards et al. 2004). We analysed mice at E16.5, to investigate the characteristic detachment of extensions to the pial surface by GFAP-expressing glial wedge glia and the presence of Calretinin-expressing guidepost neurons (Paul et al. 2007). At E16.5 both cell types were detected at the midline in Tcf4KO mice and no general defect in the organization of the structure was observed (Figure $1 \mathrm{G}$ and $H$ ), suggesting that the midline had been properly formed.

Tcf4 knockout dysregulates genes involved in neuronal differentiation and axon guidance

The presence of SATB2 positive neurons and the formation of a midline in Tcf4KO mice raised the possibility that TCF-4 may regulate in particular the formation of the axonal tracts by SATB2 expressing neurons. To identify downstream targets and pathways of TCF-4 in the control of forebrain commissure formation, scRNA-seq was conducted from E18.5 neocortices. After rigorous filtering for viable cells, 8,887 cells 
118 were analysed for the WT and 5,309 for the KO. Cell clustering was performed using

119 Seurat and cell types were assigned using known markers (Figure 2A) (Butler et al.

120 2018; Stuart et al. 2019). All expected major cell types were detected and WT and

$121 \mathrm{KO}$ cells clustered together regardless of their genotype (Figure 2B).

122 To define TCF-4-dependent networks in commissure forming neurons, the MAST

123 algorithm was used to determine differentially expressed genes (DEGs) between

124 Satb2 expressing glutamatergic WT (2,890 cells) and KO (1,328 cells) neurons

125 (Figure 2C and Table S1) (Finak et al. 2015). Upregulated genes (97 genes) were

126 associated with GO terms for ribosomes and gene expression (Figure 2D). GO terms

127 for downregulated genes (131 genes) included gene enrichments for neuron

128 development (e.g. Bcl11a, Cux1, Dab1 and Pou3f2) and differentiation (e.g. Dok5,

129 Rab3a, Sept7 and Tubb3) as well as axon guidance (e.g. Dcx, Nrp1, Plxna4, and

130 Robo2) (Figure 2D and E).

131 Analysis of unique molecular identifiers (UMIs), number of genes and the percentage

132 of mitochondrial genes revealed that $\mathrm{KO}$ cells had in general a lower number of

133 expressed genes and UMls. We therefore limited the data to cells with less than 4000

134 UMls, yielding 1057 WT and $1246 \mathrm{KO}$ cells and re-analyzed DEG and GO term

135 enrichment to account for potential bias introduced by differences in gene and cell

136 number in the Satb2 cluster. Most DEGs and GO terms remained the same indicating

137 the biological relevance of our findings (Table S2).

138 Collectively, these findings molecularly confirm the anatomical observation that Tcf4

139 knockout affects the expression of a gene network in Satb2 neurons, that is involved

140 in commissure and neuron projection development.

141 TCF-4 modulates the regulon activity of neurodevelopmental transcription

\section{2 factors}

143 We next aimed to investigate the influence of TCF-4 on gene regulatory networks 144 (GRNs). GRNs were calculated using the R package of SCENIC (Aibar et al. 2017).

145 Identified regulons were binarized to generate an ON/OFF state (Figure 3A). $R e-$ 146 clustering displayed a partitioning of cells between the two genotypes with only 147 marginal overlap (Figure 3A). Regulons were sorted into three categories: In the first, 148 the regulon was primarily active in the WT. In the second, there was no differential 149 activity between the genotypes, and in the third, the regulon was predominantly 150 active in the KO. Differentially active regulons mostly fell into the first category [e.g. 
151 Ctcf, Foxg1, Smarca4 (also known as Brg1), Cux1, Pou3f3 (also known as Brn1), 152 and Sox11] (Figure 3B and C and Table S2). As with the DEG analysis, we repeated 153 the analysis with the limited Satb2 dataset and replicated these findings (Table S3).

154 Further analysis was therefore done with the original dataset.

155 Examination of the differentially active regulons revealed that most regulon heads 156 functioned as TFs. Interestingly, the respective genes were to a high extent 157 associated with autism spectrum disorders (ASD), intellectual disability (ID) and 158 schizophrenia [ASD: 26 genes; 32.10\%; e.g. FOXG1; ID: 10 genes; 12.35\%; e.g. 159 CTCF; Schizophrenia: 13 genes; 16.05\%; e.g. SOX11 (Figure 3D)](Gregor et al. 160 2013; Kortum et al. 2011; Sun et al. 2020). To our surprise, these TFs generally did 161 not belong to the bHLH TF family, which constitutes the canonical interaction 162 partners of TCF-4 (bHLH factors: 3.70\%; Other: 96.30\%) (Figure 3E). In addition, the 163 vast majority of regulators did not appear to be downstream targets of TCF-4 as they 164 were mostly not differentially expressed in the KO (DE: 6.17\%; Not DE: 93.83\%) 165 (Figure 3E). This observation raised the question of how the loss of TCF-4 impacted 166 on regulon activity. A recent in vitro study suggested that TCF-4 may interact with 167 TFs outside the bHLH family (Moen et al. 2017), leading to the hypothesis that TCF-4 168 interacts with the regulators and thereby modulates their activity. We thus focused on 169 potential interactions regulating genes involved in neurogenesis or neuron 170 differentiation. To ensure a focus on the robustly expressed regulons, we required 171 the selected regulators to be expressed in at least one quarter of the Satb2 172 expressing cells (Table S4). Five regulon heads [Foxg1, Smarca4 (also known as 173 Brg1), Cux1, Pou3f3 (also known as Brn1), and Sox11] were selected for validation 174 (Figure 3C). CUX1 and POU3F3 are specific markers for layer II/III neurons, whereas 175 FOXG1, SMARCA4 and SOX11 are broadly expressed during neuronal 176 differentiation (Bergsland et al. 2006; Campbell et al. 2008; Deng et al. 2015; Miyoshi 177 and Fishell 2012; Molyneaux et al. 2007; Seo 2004). Staining of neocortical tissue at 178 E18.5, showed that TCF-4 was co-expressed with SOX11, FOXG1, SMARCA4 and 179 POU3F3 (Figure 3F). In vitro co-immunoprecipitation assays confirmed that the long 180 TCF-4 isoform has the potential to biochemically interact with all these TFs (Figure 181 3G). Moreover, co-immunoprecipitation assays from E18.5 neocortex lysates 182 validated the interaction of TCF-4 with SOX11 in vivo (Figure $3 \mathrm{H}$ ). 
183 Thus, TCF-4 has the ability to biochemically interact with a wide variety of TFs and 184 chromatin remodelers involved in neurogenesis and neuronal differentiation and may thereby modulate their activity during commissure development.

\section{TCF-4 and SOX11 act synergistically during commissural development}

187

188

189

190

191

192

193

194

195

196

197

198

199

200

201

202

203

204

205

206

207

208

209

210

211

212

213

214

215

We focused our successive investigation on the interaction of TCF-4 and SOX11. SOX11 contributes to an evolutionary conserved program controlling axonal tract formation of corticospinal neurons (Shim et al. 2012). SOX11's importance for human neurodevelopment is demonstrated by its causal link to a Coffin-Siris-like syndrome (OMIM 615886), a neurodevelopmental disease characterised by microcephaly and intellectual disability (Hempel et al. 2016; Turan et al. 2019). Assessing the mRNA levels in the Satb2 cluster, Sox11 was found to be expressed in almost every cell, rendering it the most commonly expressed regulator examined.

To evaluate the functional interaction of TCF-4 and SOX11 in vivo, Tcf4 and Sox11 haploinsufficient mice were crossed to generate WT, Tcf4, Sox11 and double Tcf4 and Sox11 haploinsufficient littermates. Commissural systems in P56 brains were visualized by Luxol fast blue staining. WT and Sox11 haploinsufficient mice showed no commissural phenotype (Figure 4A). In line with a previous report, Tcf4 haploinsufficient animals had a mildly shortened CC (data not shown) (Jung et al. 2018). This phenotype was greatly aggravated by the additional haploinsufficiency of Sox11 as double haploinsufficient mice showed the most severe truncation of the CC with only the most rostral part of the CC remaining (agenesis of the splenium and caudal part of the body) (Figure 4A). Moreover, only a rudimentary AC (1 out of 5 animals) or a complete agenesis of the AC (4 out 5 animals) was observed in the double haploinsufficient mice (Figure 4A).

We next asked which genes may be common target genes of both TFs and thus may be involved in commissure development. Hence, we compared the predicted regulon targets of SOX11 from the GRN analysis and the list of DEGs in the Tcf4KO. The intersection of the datasets yielded a list of 73 genes (Figure 4B and Table S3), which similarly to the differentially active regulons were often associated with autism spectrum disorders, intellectual disability and schizophrenia [ASD: 31 genes; 42.47\%; e.g. GRIA2; ID: 14 genes; 19.18\%; e.g. DCX; Schizophrenia: 22 genes; 30.14\%; e.g. PLXNA2 (Figure 4C)] (Mah et al. 2006; Pilz et al. 1998; Salpietro et al. 2019). Furthermore, GO term analysis revealed an enrichment for genes involved in 
216 axonogenesis (Figure 4D and Table S3). From these associated genes Plxna2, a

217 gene involved in semaphorin plexin signalling for axon guidance (Mah et al. 2006;

218 Mitsogiannis et al. 2017; Rohm et al. 2000) and Dcx, a gene essential for proper 219 neuronal morphology, migration and axon guidance were selected for further 220 investigation (Deuel et al. 2006; Fu et al. 2013; Karl et al. 2005; Koizumi et al. 2006).

221 Evolutionary conserved regions upstream of or at the promotor, which contained 222 conserved binding sites for TCF-4 and SOX11, were cloned into luciferase reporter 223 plasmids and then transfected into HEK293T cells together with expression plasmids 224 for Tcf4 and Sox11. SOX11 alone induced robust Dcx and PIxna2 reporter activity. 225 TCF-4 alone only marginally induced Plxna2 and Dcx activity but strongly potentiated 226 SOX11 induced reporter activities (DcX: SOX11 vs. TCF4+SOX11: p-value = 0.0059; 227 TCF4 vs. TCF4+SOX11: $\mathrm{p}$-value $=0.0011$; Plxna2: SOX11 vs. TCF4+SOX11: $\mathrm{p}$ 228 value $=0.0018$; TCF4 vs. TCF4+SOX11: $p$-value $=0.0021)$ (Figure 4B and C).

229 Collectively, these results indicate the cooperative interaction of TCF-4 and SOX11 in $230 \mathrm{AC}$ and $\mathrm{CC}$ formation by activating gene expression and their importance in 231 axonogenesis and axon guidance.

\section{Discussion}

233 Interhemispheric connections are central for higher brain function by integrating 234 information from both hemispheres (Constantinidis and Klingberg 2016; Hedden and 235 Gabrieli 2004). Here, we show that Tcf4 knockout severely disrupts cortex 236 development, especially commissure formation. We provide scRNA-Seq and 237 biochemical evidence that positions the bHLH transcription factor TCF-4 at the centre 238 of a large regulatory network for forebrain commissure formation. Of particular 239 interest is the finding that in this network TCF-4 interacts with multiple intellectual 240 disability, autism and schizophrenia associated transcriptional regulators raising the 241 possibility that the TCF-4 dependent regulatory network in commissure formation 242 may be relevant for the pathogenesis of neurodevelopmental and -psychiatric 243 disorders.

244 Previous analysis revealed the existence of multiple TCF-4 isoforms (Sepp et al. 2011). TCF-4A (short isoform) and TCF-4B (longest isoform) have been identified as 246 the two main TCF-4 isoforms, yet their specific function is presently not understood. 247 The isoforms of TCF-4 differ in their domain structure as the longest isoform contains 248 an additional activation domain, the only nuclear localization signal and another 
repressor domain. In addition, analysis of transactivation efficiency has shown that 250 TCF-4B has a higher capacity to induce gene expression than its shorter 251 counterparts (Sepp et al. 2011). The present Tcf4KO mouse model displays residual 252 expression of a short isoform of TCF-4 (TCF-4A), yet the fact that a loss of forebrain 253 commissures was observed, strongly suggests that the longest isoform has singular 254 functions in commissural formation. In this regard, future studies should compare the ability of TCF-4 isoforms for interaction with the identified transcription factor network and should map the respective interaction domains in the TCF-4 protein. An alternative, however, less likely explanation, given the additional functional domains of the long TCF-4B isoform would be that commissural development is highly dependent on TCF-4 dosage irrespective of the expressed isoforms.

260 Callosal abnormalities have been described in patients with PTHS who carry loss-of261 function mutations in the bHLH domain (Amiel et al. 2007; Jung et al. 2018; Zweier et 262 al. 2007). Disruption of the bHLH domain results in impaired DNA-binding affecting 263 the transcriptional function of all TCF-4 isoforms (Sepp et al. 2012). Mutations in the 264 first seven exons of TCF4, which do not affect the bHLH domain and may allow for the expression of shorter isoforms with an intact bHLH domain have been found in patients with moderate ID (Bedeschi et al. 2017). The present data raise the interesting possibility that such mutations may be sufficient to disrupt the function of TCF-4 in the development of interhemispheric connectivity and it would be interesting to investigate if these patients also display abnormalities in intercortical connectivity.

270 In line with a previous study by Li and colleagues (Li et al. 2019), who analysed mice 271 homozygously carrying a loss-of-function mutation affecting the bHLH domain of 272 TCF-4, we found that loss of TCF-4 promotes the generation of SATB2+ neurons at 273 the expense of deep layer neurons. While we have not analysed the molecular basis 274 of these alterations, these data indicate that the loss of the commissural system in 275 Tcf4KO mice is not the result of a failure to generate interhemispheric projection 276 neurons and that TCF-4 is dispensable for the specification of SATB2+ neurons.

277 Dysplasia of the commissure system may not only be caused by impaired 278 development of the respective projection neurons, but also by the failure to properly 279 form a midline (Richards et al. 2004). In our analyses, the cellular composition of the 280 midline appeared unaffected. At this point, we cannot fully exclude the possibility that 281 subtle defects in midline cell composition and the erroneous display of axonal 282 guidance cues contributed to the CC defects. The failed formation of the AC and the 
283 hippocampal commissure, though, hints at a general defect of neurons for

284 commissure formation as these structures do not depend on midline fusion (Raybaud 285 2019).

286 While this study was in review, Mesman and colleagues reported the agenesis of the 287 forebrain commissure system in a different Tcf4 knockout mouse model (Mesman et 288 al. 2020), which underlines the importance of TCF-4 in establishing interhemispheric 289 connectivity. In contrast to our study, Mesman and colleagues found subtle defects in 290 midline formation (Mesman et al. 2020). These phenotypic differences may be 291 explained by the different genetic setup of the respective Tcf4KO models. While the present Tcf4KO model allowed for the residual expression of shorter TCF-4 isoforms 293 with a functional bHLH domain, the Tcf4 KO strain analysed by Mesman and 294 colleagues harboured a mutation that removed the DNA binding bHLH domain from 295 all isoforms (Mesman et al. 2020). Hence, future studies should address to what 296 extent different TC-F4 isoforms contribute to the development of the midline.

297 Bulk RNA-Sequencing analyses of the developing murine neocortex of Tcf4KO mice 298 showed that TCF-4 regulates a diverse set of genes with functions in cell 299 proliferation, neuronal differentiation, and neurotransmitter release ( $\mathrm{Li}$ et al. 2019; 300 Mesman et al. 2020), which reflects TCF4's pleiotropic functions in cortical 301 development ( $\mathrm{Li}$ et al. 2019; Mesman et al. 2020; Page et al. 2017). However, given 302 the broad expression of TCF4 (Jung et al. 2018) and the considerable cellular 303 diversity in the developing neocortex, bulk RNA-Sequencing data is not ideally suited 304 to molecularly explain the complex phenotype of Tcf4KO mice and to identify cell305 type and or stage-specific TCF-4 dependent mechanisms. In the present study, we 306 used comparative single cell RNA-Sequencing analysis to zoom in onto the TCF-4307 dependent transcriptome in Satb2-expressing neurons. We thereby uncovered that 308 TCF-4 regulates genes with functions in axon guidance and neuronal and axonal 309 development in this cell population, which provides a molecular explanation for the 310 commissural phenotype in Tcf4KO mice. As the present data set contains single-cell 311 RNA sequencing data from the developing neocortex, it provides an important 312 resource to identify the cell type specific TCF-4 dependent transcriptome for other 313 defined neocortical cell populations. Such analyses are expected to provide a better 314 understanding of how TCF-4 functions as a pleiotropic regulator of cortex 315 development. 
316 Our approach of gene regulatory network analysis enabled us to identify how TCF-4 317 may affect these downstream targets. Classically, it had been assumed that TCF-4 partners with tissue specific bHLH TFs to influence transcription. Our results together with a recent in vitro study in mouse neuronal stem cells (Moen et al. 2017) indicate that TCF-4 also interacts with a multiplicity of TFs and chromatin remodelers outside the bHLH family to modulate their transcriptional activity. Here, we provided the first in vitro and in vivo biochemical evidence for these interactions and expanded the interactome of TCF-4 in a cell type specific manner for postmitotic intercortical projection neurons. As the scRNA data set is not restricted to intercortical projection neurons, it allows to predict cell type specific TCF-4-interactors also in other neocortical cell types, which will help to promote the understanding of how TCF-4 regulates the development of distinct cell populations.

328 Current evidence suggests that CC dysgenesis significantly contributes to cognitive impairment and associative dysfunction in intellectual disability, autism, and schizophrenia (Arnone et al. 2008; Badaruddin et al. 2007; Bedeschi et al. 2006; Hallak et al. 2007; Jeret et al. 1985; Paul et al. 2007; Rao et al. 2011; Siffredi et al. 2013). Intriguingly, many of the identified interactors are associated with these disorders and several of them are themselves linked to structural abnormalities of the CC (Cargnin et al. 2018; Filatova et al. 2019; Pinero et al. 2020; Pringsheim et al. 2019; Snijders Blok et al. 2019; Tzeng et al. 2014). In-depth study of the interaction of TCF-4 with SOX11 - provided in vivo biochemical and functional evidence for cooperativity of neurodevelopmental disorder-linked genes in the generation of the commissural system and for the regulation of factors suggested in the pathogenesis of neuropsychiatric disease. We propose that the present data provides a new entry point towards understanding central dysregulated networks in the pathogenesis of autism and schizophrenia. Finally, we demonstrate that ScRNA-Seq data can be harnessed to predict interaction partners of proteins. This powerful approach will be valuable to infer cell type specific transcription factor networks from complex tissues thereby enabling the discovery of regulatory networks in development, physiology and disease. 


\section{Material and Methods}

\section{Experimental models}

351 All experiments were carried out in accordance with the European Communities 352 Council Directive (86/609/EEC) and were approved by the government of Middle353 Franconia. Tcf4ex4WT/lacZ mice were obtained from the Wellcome Trust Sanger 354 Institute and previously described in Jung et al. (2018) (Alleles produced for the 355 EUCOMM and EUCOMMTools projects by the Wellcome Trust Sanger Institute; MGI 356 ID: 4432303). The Sox11 $1^{\text {LacZ/WT }}$ mice were previously described (Sock et al. 2004).

357 Experiments were performed on male and female littermates between E16.5 and 358 P56. For embryonic studies, mice were bred in the afternoon and vaginal post-coitum 359 protein plug check ("Plug check") was performed the next morning. This time point 360 was defined as E0.5. Numbers of animals used in each experiment are indicated in 361 the figure legends.

362 Genotyping of the mice was done using the following primers:

363 364 365

\section{Tcf4ex4WT/lacZ}

fwd Mut fwd WT rev lacZ fwd lacZ rev

Sox $11^{\text {LacZ/WT }}$

fwd

Rev

lacZ
TCG TGG TAT CGT TAT GCG CC CCG ATG ACA GTG ATG ATG GT AAG TTA AGC TGA AGT AAA TAC CCA CA ATC ACG ACG CGC TGT ATC ACA TCG GGC AAA TAA TAT CG

GCC CGC GCA GGA GAC CGA GC CTT GTA GTC GGG GTA GTC AGC C CGC TCAGGT CAA ATT CAG AC

HEK 293T cells (ATCC, Wesel, Germany; CRL-3216) were in $10 \mathrm{~cm}$ dishes in DMEM supplemented with $10 \%$ of fetal bovine serum and $5 \mathrm{ml}$ penicillin/Streptomycin at $37^{\circ} \mathrm{C}$ and $5 \% \mathrm{CO}_{2}$.

\section{Experimental Design}

For the single-cell RNA-Sequencing (5 WT and $4 \mathrm{KO}$ samples) only samples with more than 500 cells after filtering were used to ensure a complete reproduction of cell diversity in the neocortex. Therefore, 2 samples for the WT and 2 samples for the KO 
were removed. We had to exclude one WT animal that displayed lower Tcf4 expression than the $\mathrm{KO}$ and also excluded one cluster that displayed a high background transcript expression of blood related genes such as $\mathrm{Hbb}-\mathrm{a} 1, \mathrm{Hbb}-\mathrm{a} 2$.

\section{Tissue preparation and dissection}

383

384

385

386

387

Timed pregnant mice were killed by cervical dislocation. For the E16.5, E18.5 and P0 time points, brains were dissected and fixed overnight in 4\% PFA. Tails were used for genotyping. After fixation tissue was washed repeatedly with $1 \times$ PBS and transferred to $30 \%$ sucrose in $0.1 \mathrm{M}$ phosphate buffer overnight for dehydration. Embryonic tissues were embedded in freezing media (Leica Biosystems, Richmond) and stored at $-80^{\circ} \mathrm{C}$. Adult mice were killed using $\mathrm{CO}_{2}$ and transcardially perfused with PBS for $2 \mathrm{~min}(20 \mathrm{ml} / \mathrm{min}$ ) followed by fixation with $4 \%$ paraformaldehyde (PFA) in PBS, $\mathrm{pH}$ 7.4, for $5 \mathrm{~min}$. The brains were post-fixed overnight in $4 \%$ PFA at $4^{\circ} \mathrm{C}$ followed by dehydration at $4^{\circ} \mathrm{C}$ in $30 \%$ sucrose in $0.1 \mathrm{M}$ phosphate buffer.

\section{Histology}

Embryonic tissue was cut in $10 \mu \mathrm{m}$ thin sections with a cryotom (Leica Microsystems, Wetzlar). Sections were transferred on laminated object slides, dried for $2 \mathrm{~h}$ at room temperature and stored at $-80^{\circ} \mathrm{C}$ until further use. Slides were washed once for 5 min with $1 \mathrm{x}$ PBS. For antigen retrieval, sections were treated with $10 \mathrm{mM}$ citrate buffer ( $\mathrm{pH} \mathrm{6)}$ for $11 \mathrm{~min}$ at 720 watt in the microwave. Afterwards, half of the citrate buffer was replaced by water and the sections were incubated for another $30 \mathrm{~min}$. Further steps were performed for both antigen retrieval and normal staining protocol. Slides were washed once in 1x PBS and subsequently incubated in 4\% PFA for 10 min followed by two more washing steps in 1x PBS. Tissue was permeabilized for 10 min in $0.3 \%$ Triton-X/PBS and blocked with blocking solution (10\% Donkey serum, $3 \%$ BSA and $0.1 \%$ Tween20 in PBS) for at least $1 \mathrm{~h}$ in a wet chamber at room temperature. Sections were incubated with primary antibodies [rb BRN1 (kind gift of Elisabeth Sock) 1:500); rb BRG1 (Santa Cruz, sc10768) 1:100; rb CALRETININ (Swant 7699/4) 1:500; rt CTIP2 (Abcam, 18465) 1:500; ab rb FOXG1 (Abcam, ab18259) 1:500; rb GAP43 (Abcam, ab5220) 1:500; ch GFAP (Abcam, ab4674) 1:500; ms SATB2 (Santa Cruz, sc-81376), 1:500; rat anti-SOX11 (kind gift from Johannes Glöckner) 1:500; rb TBR1 (Abcam, ab31940) 1:500; ms TCF-4 (Santa 
410 Cruz, sc393407) 1:100] diluted in blocking solution at $4^{\circ} \mathrm{C}$ overnight. Slides were 411 washed three times for 5 min with $1 \times 0.1 \%$ Tween/PBS, incubated with secondary 412 antibodies diluted in blocking solution for $2 \mathrm{~h}$ at room temperature, and washed three 413 times with 1x PBS. Nuclei were stained with DAPI (500 pg/ml in 1x PBS) for $10 \mathrm{~min}$. 414 After additional washing with 1x PBS for $5 \mathrm{~min}$, slides were mounted with $60 \mu \mathrm{l}$ 415 Mowiol (Sigma Aldrich Chemie GmbH Munich, Germany) and stored at 4 C.

416 Cell counting

417 Cell counting was done blind to avoid bias. Numbers were randomly assigned to 418 slides before imaging. Genotypes were only revealed for statistical analysis. All 419 images of the cortices were taken with the pial surface at the upper edge of the 420 picture and the ventricular surface at the lower edge. Cells in an image were counted 421 using ImageJ software and reported as the total numbers of cells per surface area of 422 the VZ.

\section{Lipophilic Tracer Analysis}

424 For the lipophilic tracer experiment P0 brains were dissected, washed once in 1xPBS 425 and dried on a soft tissue. $1 \mu \mathrm{l}$ of Dil dilution [DilC18(3), Invitrogen, Eugene, Orgeon] 426 was pipetted on one hemisphere and the brain subsequently fixed in 4\% PFA. After 427 six weeks the tissue was transferred to $30 \%$ sucrose in $0.1 \mathrm{M}$ phosphate buffer 428 overnight for dehydration, then frozen in tissue freezing media (Leica Biosystems, 429 Richmond) and stored at $-80 \mathrm{C}$. Brains were cut in $10 \mu \mathrm{m}$ thin sections with a 430 cryotom (Leica Microsystems, Wetzlar). Sections were transferred on laminated 431 object slides and dried for $2 \mathrm{~h}$ at room temperature. Slides were washed three times 432 with 1x PBS and nuclei stained with DAPI (1:10.000 in 1xPBS) for $10 \mathrm{~min}$. After

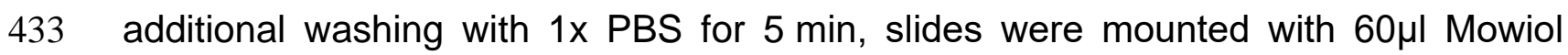
434 (Sigma Aldrich Chemie GmbH Munich, Germany) and stored at $4^{\circ} \mathrm{C}$.

\section{Luciferase Assay}

436 The ECR from the PIxna2 gene had the following positions in Mm10: chr1:194607209-194608066. The ECR was obtained by PCR from WT mouse DNA 438 and inserted into the pTATA luciferase reporter plasmid in front of a $\beta$-globin minimal 439 promoter. The hDCX-Promotor plasmid has been described before (Karl et al. 2005). 
440 HEK cells were seeded in a density of 80.000 cells per well in a 24 well plate and 441 transfected the next day. $400 \mathrm{ng}$ of CAG-GFP-based expression vectors (CAG-GFP ; 442 CAG-Sox11-IRES-GFP (Balta et al. 2018); CAG-TCF-4-IRES-GFP (Jung et al. 443 2018)), 200 ng of luciferase reporter (hDCX-pGL3 (Karl et al. 2005) and pTataLuc444 Plxna2) and $10 \mathrm{ng}$ of Renilla expression plasmid per well were transfected using 445 JETPEI (Polyplus transfection, 101-10 N) according to the manufacturers' instruction. 446 Three wells were transfected per condition as technical replicates. After $48 \mathrm{~h}$ 447 Luciferase assay was performed according to manufacturers' instruction using the 448 Dual-Luciferase Reporter Assay System Kit (Promega).

\section{$449 \quad$ Luxol fast blue staining}

450 To stain for myelin with luxol fast blue (Polyscience, Hirschberg an der Bergstraße) 451 free floating sections were washed two times with 1x PBS, mounted on coated 452 adhesive glass slides and dried for at least 2 hours at RT. The glass slides were 453 incubated in luxol fast blue solution at $57^{\circ} \mathrm{C}$ overnight and then washed one time in $45495 \%$ ethanol and one time in distilled water. The staining was differentiated in lithium 455 carbonate solution for 3 min followed by incubation in $70 \%$ ethanol till white and grey 456 mater was distinguishable. If this takes longer than $5 \mathrm{~min}$, the glass slides are 457 washed in distilled water again and the differentiation steps are repeated until white and grey mater are distinguishable from each other. The nuclei were stained with Mayer's hemalun solution for maximal $30 \mathrm{sec}$ and excess solution was removed by rinsing with tap water. Slides were mounted with $60 \mu \mathrm{l}$ Mowiol and stored at $4^{\circ} \mathrm{C}$.

\section{Imaging}

462 For overview images and cell counting, fluorescence signal was detected with an AF6000 Modular Systems Leica fluorescent microscope and documented with a SPOT-CCD camera and the Leica software LAS AF (Version 2.6.0.7266; Leica Microsystems, Wetzlar Germany). For the analysis of the Luxol fast blue staining, images were obtained with a Zeiss MN Imager and x 2.5 objective lens. For coexpression analysis, fluorescence signal was detected using a Zeiss LSM 780 confocal microscope with four lasers (405, 488, 550, and $633 \mathrm{~nm}$ ) and $\times 40$ objective lens. Images were processed using ImageJ. 


\section{Co-Immunoprecipitation}

473 For in vitro Co-Immunoprecipitation HEK 293T cells (ATCC, Wesel, Germany; CRL474 3216) were seeded in a density of two million cells in $10 \mathrm{~cm}$ dishes in DMEM 475 supplemented with $10 \%$ of fetal bovine serum and $5 \mathrm{ml}$ penicillin/Streptomycin. At a 476 confluency of $70-90 \%$ cells were transfected using JETPEI (Polyplus transfection, $477101-10 \mathrm{~N})$ with equal amounts of the expression vectors $(7.5 \mu \mathrm{g} / 10 \mathrm{~cm}$ dish) of CAG478 TCF-4-IRES-GFP and the predicted interaction partners [pCMV5 rBrn1(Schreiber et 479 al. 1997) ; pBJ5-hBRG1 (pBJ5 hBRG1 was a gift from Jerry Crabtree (Addgene 480 plasmid \# 17873 ; http://n2t.net/addgene:17873 ; RRID:Addgene_17873))(Khavari et 481 al. 1993); pXJ42-p200 CUX1 (pXJ42-p200 CUX1 was a gift from Alain Nepveu 482 (Addgene plasmid \# 100813 ; http://n2t.net/addgene:100813 ; 483 RRID:Addgene_100813))(Wilson et al. 2009); CAG-Foxg1-IRES-RFP; CAG-Sox11484 IRES-GFP(Balta et al. 2018)) according to the manufacturer instruction. After $48 \mathrm{~h}$, 485 cells were harvested in $1 \mathrm{ml}$ Buffer $\mathrm{A}$ [10 mM Hepes, pH 7.9, $10 \mathrm{mM} \mathrm{KCl,} 0.1 \mathrm{mM}$ 486 EDTA, pH 8.0, 0.1 mM EGTA, pH 8.0, protease inhibitor EDTA free cocktail (Roche 487 PVT GmbH Waiblingen, Germany) and Phosphatase Inhibitors Cocktail (Sigma

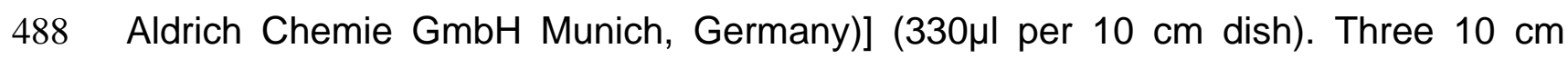
489 dishes were combined for every experiment. After addition of $100 \mu \mathrm{l}$ of $10 \%$ NP-40 490 and $84 \mu \mathrm{l}$ of $5 \mathrm{M} \mathrm{NaCl}$ the solution was vortexed for $10 \mathrm{sec}$ followed by $15 \min$ of 491 incubation on a rotating wheel at $4^{\circ} \mathrm{C}$. The homogenates were centrifuged at $49214000 x g$ for $3 \mathrm{~min}$. The supernatant was used directly for the co-immunoprecipitation 493 by mixing $300 \mu \mathrm{l}$ with $1.2 \mathrm{ml}$ of TEN-Buffer [10 mM Tris, $\mathrm{pH}$ 7.4, $0.05 \mathrm{mM}$ EDTA, 50 $494 \mathrm{mM} \mathrm{NaCl}, 0.25 \%$ 10\%NP40, protease inhibitor EDTA free cocktail (Roche PVT $495 \mathrm{GmbH}$ Waiblingen, Germany) and Phosphatase Inhibitors Cocktail (Sigma Aldrich 496 Chemie GmbH Munich, Germany)] and $2 \mu$ of ms TCF-4-antibody (Santa Cruz, 497 sc393407), $2 \mu \mathrm{l}$ of ms BrdU-antibody (BD Bioscience, B44) (Control for unspecific 498 binding to mouse antibodies), or nothing to control for unspecific binding to Protein $A$ 499 Agarose Beads, Fast Flow (GE Healthcare Bio-Sciences AB, Uppsala, Sweden). An 500 appropriate amount of the supernatant was kept as Input. Prepared probes were 501 incubated on a rotating wheel at $4^{\circ} \mathrm{C}$ overnight. $30 \mu \mathrm{l}$ of Protein A Agarose Beads, 502 Fast Flow (Millipore-Merck, Darmstadt) in TEN-Buffer (1:1) were added and the 503 samples were rotated for another $3 \mathrm{~h}$ at $4^{\circ} \mathrm{C}$. Samples were centrifuged for $5 \mathrm{~min}$ at 
$5041200 \times \mathrm{xg}$ and the supernatant was discarded. Beads were then washed three times with $500 \mu \mathrm{l}$ of TEN-Buffer and frozen at $-80^{\circ} \mathrm{C}$. For Western Blot analysis $30 \mu \mathrm{l}$ of $3 x$ Laemmli buffer was added to the beads and incubated at $95^{\circ} \mathrm{C}$ for $5 \mathrm{~min} .30 \mu \mathrm{l}$ of the samples were loaded on $10 \% 1,5 \mathrm{~mm}$ SDS gels.

508 For in vivo Co-Immunoprecipitation, neocortices of E18.5 WT embryos were 509 dissected and either used directly or stored at $-80^{\circ} \mathrm{C}$ until further use. Two cortices

510 were merged and homogenized in $1 \mathrm{ml}$ of Buffer A. Samples were treated as 511 described above. Antibodies used were rb SOX11-antibody (Abcam, ab134107) and $512 \mathrm{rb}$ EPHA3-antibody (Abcam, ab110465). For Western Blot analysis $50 \mu \mathrm{l}$ of $5133 x$ Laemmli buffer was added to the beads and incubated by $95^{\circ} \mathrm{C}$ for $5 \mathrm{~min} .50 \mu \mathrm{l}$ of 514 the samples were loaded on 10\% 1,5 mm SDS gels.

515 Western Blot

516 Protein extracted from E18.5 WT or KO cortices were obtained by homogenizing the tissue in RIPA buffer [50 mM Tris- $\mathrm{HCl}, \mathrm{pH} 8.0,150 \mathrm{mM} \mathrm{NaCl}, 1 \%$ Nonidet P-40, 0.5\%

518 Na-deoxycholate, 0.1\% SDS, 2 mM EDTA, protease inhibitor EDTA free cocktail 519 (Roche PVT GmbH Waiblingen, Germany) and Phosphatase Inhibitors Cocktail 520 (Sigma Aldrich Chemie GmbH Munich, Germany)] followed by incubation for 30 min 521 on ice. The post-nuclear supernatant of the lysate was obtained by centrifugation at $5222000 x g$ for $10 \mathrm{~min}$ at $4^{\circ} \mathrm{C}$. Protein content was measured using the Pierce BCA 523 protein assay (Thermo Scientific, Warrington, UK). For Western Blot analysis $30 \mu \mathrm{g}$ 524 of protein were loaded on a 10\% 1mm SDS-PAGE gel. Gels underwent wet transfer onto a nitrocellulose membrane. Membranes were blocked in PBS with $0.1 \%$ Tween 20 (PBS-T). Incubation with primary antibodies [rb TCF-4 (Abcam; ab130014) 1:500] 527 diluted in 5\% BSA in PBS-T was performed overnight at $4^{\circ} \mathrm{C}$ and was followed by 528 three times washing with PBS-T. Secondary antibodies were diluted in PBST and 529 incubated with the membranes for at least $1 \mathrm{~h}$ at room temperature followed by 530 washing with PBS-T. Membranes were treated with Clarity Western Enhanced 531 Chemiluminescence Substrate (Bio-Rad) and visualized with Fusion-SL (PeqLab). Images were processed via Fusion (PeqLab). 


\section{Single-cell RNA sequencing and analysis}

\section{Single-Cell Isolation of E18.5 cortex tissue}

538 Neocortices of E18.5 embryos were dissected under a binocular. Each cortex was 539 incubated in $150 \mu \mathrm{l}$ of Ovomucoid-Mix [1.15 mg/ml Trypsin-Inhibitor (Sigma Aldrich

540 Chemie GmbH Munich, Germany), 0.53 mg/ml BSA, 400 ng/ml DNase I Type IV 541 (Roche PVT GmbH Waiblingen, Germany) in L15 medium (Gibco)] and carefully cut 542 into small pieces. After addition of $150 \mu$ of Papain-Mix (30 U/ml Papain (Sigma 543 Aldrich Chemie GmbH Munich, Germany), 0.24 mg/ml Cysteine (Sigma Aldrich 544 Chemie GmbH Munich, Germany), $40 \mu \mathrm{g} / \mathrm{ml}$ DNase I Type IV (Roche PVT GmbH 545 Waiblingen, Germany)) samples were incubated for $15-20 \mathrm{~min}$ at $37^{\circ} \mathrm{C}$. To dissociate 546 the cells. $300 \mu$ of Ovomucoid were added followed by a 5 min incubation at room 547 temperature. The tissue was then triturated with fire-polished glass pipettes and 548 transferred to $10 \mathrm{ml}$ of L15 medium. To obtain the cells, the solution was centrifuged 549 for $5 \mathrm{~min}$ at $90 \mathrm{xg}$ and about $9.5 \mathrm{ml}$ of the supernatant was discarded. Cells were 550 resuspended in the remaining media and strained through a cell strainer (Mesh size: $55140 \mu \mathrm{m})$ to remove clumps. Cell density was determined using a Neubauer chamber. 552 Libraries were prepared using the Chromium Controller and the Chromium Single 553 Cell 3' Reagent Kit v2 (10X Genomics, Pleasanton, CA). Single cell suspensions 554 were diluted in nuclease-free water according to manufacturer instructions to obtain a 555 targeted cell count of 5000. cDNA synthesis, barcoding, and library preparation were 556 then carried out according to the manufacturers' instructions. The libraries were 557 sequenced on an Illumina HiSeq 2500 (Illumina, San Diego) with a read length of 26 558 bp for read 1 (cell barcode and unique molecule identifier (UMI)), 8 bp i7 index read 559 (sample barcode), and 98 bp for read 2 (actual RNA read). Reads were first 560 sequenced in the rapid run mode, allowing for fine-tuning of sample ratios in the 561 following high-output run. Combining the data from both flow cells yielded 562 approximately $200 \mathrm{M}$ reads per mouse.

Data Processing for scRNA-seq Analysis Using Cell Ranger and Seurat

564 The reads were de-multiplexed using Cell Ranger (version 2.1.1, 10X Genomics) 565 mkfastq and read quality was assessed by FastQC (version 0.11.8, Babraham 
566 bioinformatics). For mapping the reads to the mm10 genome (10X Reference 2.1.0,

567 GRCm38, Ensembl 84) and to identify single cells the standard Cell Ranger workflow 568 was used. Common quality control measures for scRNA-seq (gene count per cell,

569 UMI count per cell, percent of mitochondrial transcripts) were calculated using the 570 Seurat R package (version 2.3.4) (Butler et al. 2018; Satija et al. 2015). The analyses 571 were performed for genotypes and for each mouse individually. Quality control 572 thresholds were set to $1,000-5,000$ genes per cells, $1800-10000$ UMls and $<6 \%$ of 573 mitochondrial transcripts. Only samples with more than 500 cells after filtering were 574 used to ensure a complete reproduction of cell diversity in the neocortex. 3 samples 575 for WT and 2 samples for KO were used for further analysis. We had to exclude one 576 WT animal that displayed lower Tcf4 expression than the KO and we also excluded 577 cells that displayed a high background transcript expression of blood related genes 578 such as Hbb-a1, Hbb-a2.

579 scRNA-Seq clustering and differential gene expression analysis using Seurat

580 Clustering of the cells was performed using the Seurat packages for $\mathrm{R}$ following the 581 vignettes of the authors (Butler et al. 2018; Stuart et al. 2019). Cluster identity was 582 defined using known marker expression for the different cell types. To extract SATB2 583 expressing glutamatergic cells, the data was subset by accepting only cells belonging 584 to the intermediate progenitor, newborn neuron, deep layer and upper layer clusters 585 with counts for SATB2 above 0 . Differentially expressed genes between the two 586 genotypes were determined using the MAST algorithm as implemented 587 implementation in Seurat (Finak et al. 2015). GO-terms were identified with the 588 Panther online tool (GO- Slim biological process and GO biological process 589 complete) (http://www.pantherdb.org) (Mi et al. 2019).

\section{Gene regulatory network analysis by SCENIC}

591 Assessment of gene regulatory networks (GRNs) was performed using the $R$ package SCENIC (version 2) (Aibar et al. 2017). Only genes expressed in at least 593 three cells were considered for analysis. The analysis was performed according to 594 the packages vignettes. After gene regulatory networks defined, the networks were 595 binarized. To that end a threshold was set at the mean of the area under the curve. 596 In cells below the threshold the GRN was considered not active (OFF) whereas in 
597 cells above it was considered active (ON). As cells clustered apart according to the 598 genotype, a list of GRNs was identified which where only active in one genotype. It 599 was hypothesised that TCF-4 interacts with the heads of the GRNs and modulates 600 their activity. To obtain a manageable list of candidate genes which might interact 601 with TCF-4 the list of GRNs heads were analysed using the Panther online tool (Mi et 602 al. 2019). Only genes associated with the GO terms neurogenesis/neuron 603 differentiation and with at least an expression in 1/4 of the cells in the SATB2 cluster 604 were chosen for validation. Common targets of TCF-4 and SOX11 were found by 605 intersecting the list of DEGs from the Satb2 cluster with the predicted targets of the 606 Sox11 regulon. Disease association was determined by querying the list of 607 differentially active regulons and common targets of TCF-4 and Sox11 in the 608 DisGeNET database (https://disgenet.org)(Pinero et al. 2020).

\section{Statistical analysis}

610 To determine statistical significance Mann-Whitney-U test was performed using the 611 ggplot2 implementation of $\mathrm{R}\left({ }^{*}, \mathrm{P} \leq 0.05 ;{ }^{* *}, \mathrm{P} \leq 0.01,{ }^{* *}, \mathrm{P} \leq 0.001\right)$ if not otherwise 612 indicated. $\mathrm{n}$ is indicated in the figure legends. Data is depicted as mean $\pm \mathrm{SD}$.

613 To determine whether differences in luciferase activities (Figure 4B and C) were 614 statistically significant, a two-tailed student's t-test was performed using the ggplot2 615 implementation of $\mathrm{R}\left({ }^{*}, \mathrm{P} \leq 0.05 ;{ }^{* *}, \mathrm{P} \leq 0.01,{ }^{* * *}, \mathrm{P} \leq 0.001\right)$. Data is depicted as mean $616 \pm$ SD. Results from independent transfections were treated as biological replicates.

\section{Data and code availability}

618 The accession number for the single-cell RNA Sequencing of E18.5 neocortices is 619 GEO: GSE147247.

\section{Acknowledgments}

621 We thank Silvia Cappello, Michael Wegner and all members of the Institutes of 622 Human Genetics and Biochemistry for helpful discussions.

623 This work was supported by the Deutsche Forschungsgemeinschaft (DFG, German 624 Research Foundation) [Grant numbers 270949263/ GRK2162 and LI 858/ 9-1], by 625 the Interdisciplinary Centre for Clinical Research Erlangen [Grant number E16 to 626 D.C.L. and A.R.], and the Bavarian Research Network "ForINTER" to D.C.L.. 
M.T.W. is member of the research training group 2162 "Neurodevelopment and

628 Vulnerability of the Central Nervous System" of the Deutsche

Forschungsgemeinschaft (DFG GRK2162/1).

\section{Author contributions}

632 Conceptualization, M.-T.W., D.C.L., A.R; Investigation, M.-T.W., P.K., A.B.E., Formal 633 analysis, M.-T.W., P.K., A.B.E., D.C.L., A.R; Resources and Funding acquisition, 634 D.C.L., A.R; Reagents, E.S.; Writing-Original draft, M.-T.W., D.C.L., A.R.; Writing635 Review and Editing, M.-T.W., D.C.L., A.R.; Supervision: D.C.L., A.R.

636 Declaration of Interests

637 The authors declare no competing interests.

\section{References}

639 Aibar S, Gonzalez-Blas CB, Moerman T, Huynh-Thu VA, Imrichova H, Hulselmans G, 640 Rambow F, Marine JC, Geurts P, Aerts J, van den Oord J, Atak ZK, Wouters J, Aerts 641 S (2017) SCENIC: single-cell regulatory network inference and clustering. Nat 642 Methods 14: 1083-1086. doi: 10.1038/nmeth.4463

643 Alcamo EA, Chirivella L, Dautzenberg M, Dobreva G, Farinas I, Grosschedl R, 644 McConnell SK (2008) Satb2 regulates callosal projection neuron identity in the 645 developing cerebral cortex. Neuron 57: 364-77. doi: 10.1016/j.neuron.2007.12.012

646 Amiel J, Rio M, de Pontual L, Redon R, Malan V, Boddaert N, Plouin P, Carter NP, 647 Lyonnet S, Munnich A, Colleaux L (2007) Mutations in TCF4, encoding a class I 648 basic helix-loop-helix transcription factor, are responsible for Pitt-Hopkins syndrome, 649 a severe epileptic encephalopathy associated with autonomic dysfunction. Am J Hum 650 Genet 80: 988-93. doi: 10.1086/515582

651 Arnone D, Mclntosh AM, Tan GM, Ebmeier KP (2008) Meta-analysis of magnetic 652 resonance imaging studies of the corpus callosum in schizophrenia. Schizophr Res 101: 124-32. doi: 10.1016/j.schres.2008.01.005

Badaruddin DH, Andrews GL, Bolte S, Schilmoeller KJ, Schilmoeller G, Paul LK, Brown WS (2007) Social and behavioral problems of children with agenesis of the corpus callosum. Child Psychiatry Hum Dev 38: 287-302. doi: 10.1007/s10578-0070065-6

Balta EA, Schaffner I, Wittmann MT, Sock E, von Zweydorf F, von Wittgenstein J, Steib K, Heim B, Kremmer E, Haberle BM, Ueffing M, Lie DC, Gloeckner CJ (2018) Phosphorylation of the neurogenic transcription factor SOX11 on serine 133 modulates neuronal morphogenesis. Sci Rep 8: 16196. doi: 10.1038/s41598-01834480- $x$ 
Agenesis of the corpus callosum: clinical and genetic study in 63 young patients. Pediatr Neurol 34: 186-93. doi: 10.1016/j.pediatrneurol.2005.08.008

Bedeschi MF, Marangi G, Calvello MR, Ricciardi S, Leone FPC, Baccarin M, Guerneri S, Orteschi D, Murdolo M, Lattante S, Frangella S, Keena B, Harr MH, Zackai E, Zollino M (2017) Impairment of different protein domains causes variable clinical presentation within Pitt-Hopkins syndrome and suggests intragenic molecular syndromology of TCF4. Eur J Med Genet 60: 565-571. doi: 10.1016/j.ejmg.2017.08.004

Bergsland M, Werme M, Malewicz M, Perlmann T, Muhr J (2006) The establishment of neuronal properties is controlled by Sox4 and Sox11. Genes Dev 20: 3475-86. doi: 10.1101/gad.403406

Bertrand N, Castro DS, Guillemot F (2002) Proneural genes and the specification of neural cell types. Nat Rev Neurosci 3: 517-30. doi: 10.1038/nrn874

Britanova O, de Juan Romero C, Cheung A, Kwan KY, Schwark M, Gyorgy A, Vogel T, Akopov S, Mitkovski M, Agoston D, Sestan N, Molnar Z, Tarabykin V (2008) Satb2 is a postmitotic determinant for upper-layer neuron specification in the neocortex. Neuron 57: 378-92. doi: 10.1016/j.neuron.2007.12.028

Butler A, Hoffman P, Smibert P, Papalexi E, Satija R (2018) Integrating single-cell transcriptomic data across different conditions, technologies, and species. Nat Biotechnol. doi: 10.1038/nbt.4096

Campbell CE, Piper M, Plachez C, Yeh YT, Baizer JS, Osinski JM, Litwack ED, Richards LJ, Gronostajski RM (2008) The transcription factor Nfix is essential for normal brain development. BMC Dev Biol 8: 52. doi: 10.1186/1471-213X-8-52

Cargnin F, Kwon JS, Katzman S, Chen B, Lee JW, Lee SK (2018) FOXG1 Orchestrates Neocortical Organization and Cortico-Cortical Connections. Neuron 100: 1083-1096 e5. doi: 10.1016/j.neuron.2018.10.016

Constantinidis C, Klingberg T (2016) The neuroscience of working memory capacity and training. Nat Rev Neurosci 17: 438-49. doi: 10.1038/nrn.2016.43

De Rubeis S, He X, Goldberg AP, Poultney CS, Samocha K, Cicek AE, Kou Y, Liu L, Fromer M, Walker S, Singh T, Klei L, Kosmicki J, Shih-Chen F, Aleksic B, Biscaldi M, Bolton PF, Brownfeld JM, Cai J, Campbell NG, Carracedo A, Chahrour MH, Chiocchetti AG, Coon H, Crawford EL, Curran SR, Dawson G, Duketis E, Fernandez BA, Gallagher L, Geller E, Guter SJ, Hill RS, Ionita-Laza J, Jimenz Gonzalez P, Kilpinen H, Klauck SM, Kolevzon A, Lee I, Lei I, Lei J, Lehtimaki T, Lin CF, Ma'ayan A, Marshall CR, Mclnnes AL, Neale B, Owen MJ, Ozaki N, Parellada M, Parr JR, Purcell S, Puura K, Rajagopalan D, Rehnstrom K, Reichenberg A, Sabo A, Sachse M, Sanders SJ, Schafer C, Schulte-Ruther M, Skuse D, Stevens C, Szatmari P, Tammimies K, Valladares O, Voran A, Li-San W, Weiss LA, Willsey AJ, Yu TW, Yuen RK, Study DDD, Homozygosity Mapping Collaborative for A, Consortium UK, Cook EH, Freitag CM, Gill M, Hultman CM, Lehner T, Palotie A, Schellenberg GD, Sklar P, State MW, Sutcliffe JS, Walsh CA, Scherer SW, Zwick ME, Barett JC, Cutler DJ, Roeder K, Devlin B, Daly MJ, Buxbaum JD (2014) Synaptic, transcriptional and chromatin genes disrupted in autism. Nature 515: 209-15. doi: 10.1038/nature13772

Deng L, Li G, Rao B, Li H (2015) Central nervous system-specific knockout of Brg1 causes growth retardation and neuronal degeneration. Brain Research 1622: 186195. doi: 10.1016/j.brainres.2015.06.027 
Deuel TA, Liu JS, Corbo JC, Yoo SY, Rorke-Adams LB, Walsh CA (2006) Genetic interactions between doublecortin and doublecortin-like kinase in neuronal migration and axon outgrowth. Neuron 49: 41-53. doi: 10.1016/j.neuron.2005.10.038

Edwards TJ, Sherr EH, Barkovich AJ, Richards LJ (2014) Clinical, genetic and imaging findings identify new causes for corpus callosum development syndromes. Brain 137: 1579-613. doi: 10.1093/brain/awt358

Filatova A, Rey LK, Lechler MB, Schaper J, Hempel M, Posmyk R, Szczaluba K, Santen GWE, Wieczorek D, Nuber UA (2019) Mutations in SMARCB1 and in other Coffin-Siris syndrome genes lead to various brain midline defects. Nat Commun 10: 2966. doi: 10.1038/s41467-019-10849-y

Finak G, McDavid A, Yajima M, Deng J, Gersuk V, Shalek AK, Slichter CK, Miller HW, McElrath MJ, Prlic M, Linsley PS, Gottardo R (2015) MAST: a flexible statistical framework for assessing transcriptional changes and characterizing heterogeneity in single-cell RNA sequencing data. Genome Biol 16: 278. doi: 10.1186/s13059-0150844-5

726 Fu X, Brown KJ, Yap CC, Winckler B, Jaiswal JK, Liu JS (2013) Doublecortin (Dcx) family proteins regulate filamentous actin structure in developing neurons. J Neurosci 33: 709-21. doi: 10.1523/JNEUROSCI.4603-12.2013

Gregor A, Oti M, Kouwenhoven EN, Hoyer J, Sticht H, Ekici AB, Kjaergaard S, Rauch A, Stunnenberg HG, Uebe S, Vasileiou G, Reis A, Zhou H, Zweier C (2013) De novo mutations in the genome organizer CTCF cause intellectual disability. Am J Hum Genet 93: 124-31. doi: 10.1016/j.ajhg.2013.05.007

Hallak JE, Crippa JA, Pinto JP, Machado de Sousa JP, Trzesniak C, Dursun SM, McGuire P, Deakin JF, Zuardi AW (2007) Total agenesis of the corpus callosum in a patient with childhood-onset schizophrenia. Arq Neuropsiquiatr 65: 1216-9. doi: 10.1590/s0004-282x2007000700024

Hedden T, Gabrieli JD (2004) Insights into the ageing mind: a view from cognitive neuroscience. Nat Rev Neurosci 5: 87-96. doi: 10.1038/nrn1323

Hempel A, Pagnamenta AT, Blyth M, Mansour S, McConnell V, Kou I, Ikegawa S, Tsurusaki Y, Matsumoto N, Lo-Castro A, Plessis G, Albrecht B, Battaglia A, Taylor JC, Howard MF, Keays D, Sohal AS, collaboration DDD, Kuhl SJ, Kini U, McNeill A (2016) Deletions and de novo mutations of SOX11 are associated with a neurodevelopmental disorder with features of Coffin-Siris syndrome. J Med Genet 53: 152-62. doi: 10.1136/jmedgenet-2015-103393

Jeret JS, Serur D, Wisniewski K, Fisch C (1985) Frequency of agenesis of the corpus callosum in the developmentally disabled population as determined by computerized tomography. Pediatr Neurosci 12: 101-3. doi: 10.1159/000120229

Jung M, Haberle BM, Tschaikowsky T, Wittmann MT, Balta EA, Stadler VC, Zweier C, Dorfler A, Gloeckner CJ, Lie DC (2018) Analysis of the expression pattern of the schizophrenia-risk and intellectual disability gene TCF4 in the developing and adult brain suggests a role in development and plasticity of cortical and hippocampal neurons. Mol Autism 9: 20. doi: 10.1186/s13229-018-0200-1

753 Karl C, Couillard-Despres S, Prang P, Munding M, Kilb W, Brigadski T, Plotz S, 754 Mages W, Luhmann H, Winkler J, Bogdahn U, Aigner L (2005) Neuronal precursorspecific activity of a human doublecortin regulatory sequence. J Neurochem 92: 26482. doi: 10.1111/j.1471-4159.2004.02879.x 
Khavari PA, Peterson CL, Tamkun JW, Mendel DB, Crabtree GR (1993) BRG1 contains a conserved domain of the SWI2/SNF2 family necessary for normal mitotic growth and transcription. Nature 366: 170-4. doi: 10.1038/366170a0

760 Koizumi H, Tanaka T, Gleeson JG (2006) Doublecortin-like kinase functions with

761

762

763

764

765

766

767

768

769

770

771

772

773

774

775

776

777

778

779

780

781

782

783

784

785

786

787

788

789

790

791

792

793

794

795

796

797

798

799

800 doublecortin to mediate fiber tract decussation and neuronal migration. Neuron 49: 55-66. doi: 10.1016/j.neuron.2005.10.040

Kortum F, Das S, Flindt M, Morris-Rosendahl DJ, Stefanova I, Goldstein A, Horn D, Klopocki E, Kluger G, Martin P, Rauch A, Roumer A, Saitta S, Walsh LE, Wieczorek D, Uyanik G, Kutsche K, Dobyns WB (2011) The core FOXG1 syndrome phenotype consists of postnatal microcephaly, severe mental retardation, absent language, dyskinesia, and corpus callosum hypogenesis. J Med Genet 48: 396-406. doi: 10.1136/jmg.2010.087528

Li H, Zhu Y, Morozov YM, Chen X, Page SC, Rannals MD, Maher BJ, Rakic P (2019) Disruption of TCF4 regulatory networks leads to abnormal cortical development and mental disabilities. Mol Psychiatry. doi: 10.1038/s41380-019-0353-0

Lindwall C, Fothergill T, Richards LJ (2007) Commissure formation in the mammalian forebrain. Curr Opin Neurobiol 17: 3-14. doi: 10.1016/j.conb.2007.01.008

Mah S, Nelson MR, Delisi LE, Reneland RH, Markward N, James MR, Nyholt DR, Hayward N, Handoko H, Mowry B, Kammerer S, Braun A (2006) Identification of the semaphorin receptor PLXNA2 as a candidate for susceptibility to schizophrenia. Mol Psychiatry 11: 471-8. doi: 10.1038/sj.mp.4001785

Massari ME, Murre C (2000) Helix-loop-helix proteins: regulators of transcription in eucaryotic organisms. Mol Cell Biol 20: 429-40.

Mesman S, Bakker R, Smidt MP (2020) Tcf4 encodes correct brain development during embryogenesis. Mol Cell Neurosci: 103502. doi: 10.1016/j.mcn.2020.103502

Mi H, Muruganujan A, Huang X, Ebert D, Mills C, Guo X, Thomas PD (2019) Protocol Update for large-scale genome and gene function analysis with the PANTHER classification system (v.14.0). Nat Protoc 14: 703-721. doi: 10.1038/s41596-0190128-8

Mitsogiannis MD, Little GE, Mitchell KJ (2017) Semaphorin-Plexin signaling influences early ventral telencephalic development and thalamocortical axon guidance. Neural Dev 12: 6. doi: 10.1186/s13064-017-0083-4

Miyoshi G, Fishell G (2012) Dynamic FoxG1 expression coordinates the integration of multipolar pyramidal neuron precursors into the cortical plate. Neuron 74: 1045-58. doi: 10.1016/j.neuron.2012.04.025

Moen MJ, Adams HH, Brandsma JH, Dekkers DH, Akinci U, Karkampouna S, Quevedo M, Kockx CE, Ozgur Z, van IWF, Demmers J, Poot RA (2017) An interaction network of mental disorder proteins in neural stem cells. Transl Psychiatry 7: e1082. doi: 10.1038/tp.2017.52

Molyneaux BJ, Arlotta P, Menezes JR, Macklis JD (2007) Neuronal subtype specification in the cerebral cortex. Nat Rev Neurosci 8: 427-37. doi: 10.1038/nrn2151

Navarrete K, Pedroso I, De Jong S, Stefansson H, Steinberg S, Stefansson K, Ophoff RA, Schalkwyk LC, Collier DA (2013) TCF4 (e2-2; ITF2): a schizophrenia-associated 
801

802

803

804

805

806

807

808

809

810

811

812

813

814

815

816

817

818

819

820

821

822

823

824

825

826

827

828

829

830

831

832

833

834

835

836

837

838

839

840

841

842

843

844

845

846

gene with pleiotropic effects on human disease. Am J Med Genet B Neuropsychiatr Genet 162B: 1-16. doi: 10.1002/ajmg.b.32109

Page SC, Hamersky GR, Gallo RA, Rannals MD, Calcaterra NE, Campbell MN, Mayfield B, Briley A, Phan BN, Jaffe AE, Maher BJ (2017) The schizophrenia- and autism-associated gene, transcription factor 4 regulates the columnar distribution of layer $2 / 3$ prefrontal pyramidal neurons in an activity-dependent manner. Mol Psychiatry. doi: 10.1038/mp.2017.37

Paul LK, Brown WS, Adolphs R, Tyszka JM, Richards LJ, Mukherjee P, Sherr EH (2007) Agenesis of the corpus callosum: genetic, developmental and functional aspects of connectivity. Nat Rev Neurosci 8: 287-99. doi: 10.1038/nrn2107

Pilz DT, Matsumoto N, Minnerath S, Mills P, Gleeson JG, Allen KM, Walsh CA, Barkovich AJ, Dobyns WB, Ledbetter DH, Ross ME (1998) LIS1 and XLIS (DCX) mutations cause most classical lissencephaly, but different patterns of malformation. Hum Mol Genet 7: 2029-37. doi: 10.1093/hmg/7.13.2029

Pinero J, Ramirez-Anguita JM, Sauch-Pitarch J, Ronzano F, Centeno E, Sanz F, Furlong LI (2020) The DisGeNET knowledge platform for disease genomics: 2019 update. Nucleic Acids Res 48: D845-D855. doi: 10.1093/nar/gkz1021

Pringsheim M, Mitter D, Schroder S, Warthemann R, Plumacher K, Kluger G, Baethmann M, Bast T, Braun S, Buttel HM, Conover E, Courage C, Datta AN, Eger A, Grebe TA, Hasse-Wittmer A, Heruth M, Hoft K, Kaindl AM, Karch S, Kautzky T, Korenke GC, Kruse B, Lutz RE, Omran H, Patzer S, Philippi H, Ramsey K, Rating T, Riess A, Schimmel M, Westman R, Zech FM, Zirn B, Ulmke PA, Sokpor G, Tuoc T, Leha A, Staudt M, Brockmann K (2019) Structural brain anomalies in patients with FOXG1 syndrome and in Foxg1+/- mice. Ann Clin Transl Neurol 6: 655-668. doi: 10.1002/acn3.735

Rao NP, Venkatasubramanian G, Arasappa R, Gangadhar BN (2011) Relationship between corpus callosum abnormalities and schneiderian first-rank symptoms in antipsychotic-naive schizophrenia patients. J Neuropsychiatry Clin Neurosci 23: 15562. doi: 10.1176/appi.neuropsych.23.2.155

\subsection{6/jnp.23.2.jnp155}

Raybaud C (2019) Corpus Callosum: Molecular Pathways in Mice and Human Dysgeneses. Neuroimaging Clin N Am 29: 445-459. doi: 10.1016/j.nic.2019.03.006

Richards LJ, Plachez C, Ren T (2004) Mechanisms regulating the development of the corpus callosum and its agenesis in mouse and human. Clin Genet 66: 276-89. doi: 10.1111/j.1399-0004.2004.00354.x

Rohm B, Ottemeyer A, Lohrum M, Puschel AW (2000) Plexin/neuropilin complexes mediate repulsion by the axonal guidance signal semaphorin 3A. Mech Dev 93: 95104. doi: 10.1016/s0925-4773(00)00269-0

Salpietro V, Dixon CL, Guo H, Bello OD, Vandrovcova J, Efthymiou S, Maroofian R, Heimer G, Burglen L, Valence S, Torti E, Hacke M, Rankin J, Tariq H, Colin E, Procaccio V, Striano P, Mankad K, Lieb A, Chen S, Pisani L, Bettencourt C, Mannikko R, Manole A, Brusco A, Grosso E, Ferrero GB, Armstrong-Moron J, Gueden S, Bar-Yosef O, Tzadok M, Monaghan KG, Santiago-Sim T, Person RE, Cho MT, Willaert R, Yoo Y, Chae JH, Quan Y, Wu H, Wang T, Bernier RA, Xia K, Blesson A, Jain M, Motazacker MM, Jaeger B, Schneider AL, Boysen K, Muir AM, Myers CT, Gavrilova RH, Gunderson L, Schultz-Rogers L, Klee EW, Dyment D, Osmond M, 
847 Parellada M, Llorente C, Gonzalez-Penas J, Carracedo A, Van Haeringen A, 848 Ruivenkamp C, Nava C, Heron D, Nardello R, lacomino M, Minetti C, Skabar A, 849 Fabretto A, Group SS, Raspall-Chaure M, Chez M, Tsai A, Fassi E, Shinawi M, 850 Constantino JN, De Zorzi R, Fortuna S, Kok F, Keren B, Bonneau D, Choi M, 851 Benzeev B, Zara F, Mefford HC, Scheffer IE, Clayton-Smith J, Macaya A, Rothman 852 JE, Eichler EE, Kullmann DM, Houlden H (2019) AMPA receptor GluA2 subunit 853 defects are a cause of neurodevelopmental disorders. Nat Commun 10: 3094. doi: 854 10.1038/s41467-019-10910-w

855 Satija R, Farrell JA, Gennert D, Schier AF, Regev A (2015) Spatial reconstruction of 856 single-cell gene expression data. Nat Biotechnol 33: 495-502. doi: 10.1038/nbt.3192

860 Schizophrenia Working Group of the Psychiatric Genomics C (2014) Biological 861 insights from 108 schizophrenia-associated genetic loci. Nature 511: 421-7. doi: $86210.1038 /$ nature13595

863 Schreiber J, Enderich J, Sock E, Schmidt C, Richter-Landsberg C, Wegner M (1997) 864 Redundancy of class III POU proteins in the oligodendrocyte lineage. J Biol Chem 865 272: 32286-93. doi: 10.1074/jbc.272.51.32286

866

867

868

869

870

871

872

873

874

875

876

877

878

879

880

881

882

883

884

885

886

887

888

889

890

891

892

Schizophrenia Psychiatric Genome-Wide Association Study C (2011) Genome-wide association study identifies five new schizophrenia loci. Nat Genet 43: 969-76. doi: $10.1038 / n g .940$

Seo S (2004) The SWI/SNF chromatin remodeling protein Brg1 is required for vertebrate neurogenesis and mediates transactivation of $\mathrm{Ngn}$ and NeuroD. Development 132: 105-115. doi: 10.1242/dev.01548

Sepp M, Kannike K, Eesmaa A, Urb M, Timmusk T (2011) Functional diversity of human basic helix-loop-helix transcription factor TCF4 isoforms generated by alternative 5' exon usage and splicing. PLoS One 6: e22138. doi: 10.1371/journal.pone.0022138

Sepp M, Pruunsild P, Timmusk T (2012) Pitt-Hopkins syndrome-associated mutations in TCF4 lead to variable impairment of the transcription factor function ranging from hypomorphic to dominant-negative effects. Hum Mol Genet 21: 287388. doi: $10.1093 / \mathrm{hmg} / \mathrm{dds} 112$

Shim S, Kwan KY, Li M, Lefebvre V, Sestan N (2012) Cis-regulatory control of corticospinal system development and evolution. Nature 486: 74-9. doi: 10.1038/nature11094

Siffredi V, Anderson V, Leventer RJ, Spencer-Smith MM (2013) Neuropsychological profile of agenesis of the corpus callosum: a systematic review. Dev Neuropsychol 38: 36-57. doi: 10.1080/87565641.2012.721421

Snijders Blok L, Kleefstra T, Venselaar H, Maas S, Kroes HY, Lachmeijer AMA, van Gassen KLI, Firth HV, Tomkins S, Bodek S, Study DDD, Ounap K, Wojcik MH, Cunniff C, Bergstrom K, Powis Z, Tang S, Shinde DN, Au C, Iglesias AD, Izumi K, Leonard J, Abou Tayoun A, Baker SW, Tartaglia M, Niceta M, Dentici ML, Okamoto N, Miyake N, Matsumoto N, Vitobello A, Faivre L, Philippe C, Gilissen C, Wiel L, Pfundt R, Deriziotis P, Brunner HG, Fisher SE (2019) De Novo Variants Disturbing the Transactivation Capacity of POU3F3 Cause a Characteristic Neurodevelopmental Disorder. Am J Hum Genet 105: 403-412. doi: 10.1016/j.ajhg.2019.06.007

Sock E, Rettig SD, Enderich J, Bosl MR, Tamm ER, Wegner M (2004) Gene targeting reveals a widespread role for the high-mobility-group transcription factor 
893

894

895

896

897

898

899

900

901

902

903

904

905

906

907

908

909

910

911

912

913

914

915

916

917

918

919

920

921

922

923

924

925

926

927

928

929

930

931

932

933

934

935

936

937

938

939

940

\section{Sox11 in tissue remodeling. Mol Cell Biol 24: 6635-44. doi:} 10.1128/MCB.24.15.6635-6644.2004

Stefansson H, Ophoff RA, Steinberg S, Andreassen OA, Cichon S, Rujescu D, Werge T, Pietilainen OP, Mors O, Mortensen PB, Sigurdsson E, Gustafsson O, Nyegaard M, Tuulio-Henriksson A, Ingason A, Hansen T, Suvisaari J, Lonnqvist J, Paunio T, Borglum AD, Hartmann A, Fink-Jensen A, Nordentoft M, Hougaard D, Norgaard-Pedersen B, Bottcher Y, Olesen J, Breuer R, Moller HJ, Giegling I, Rasmussen HB, Timm S, Mattheisen M, Bitter I, Rethelyi JM, Magnusdottir BB, Sigmundsson T, Olason P, Masson G, Gulcher JR, Haraldsson M, Fossdal R, Thorgeirsson TE, Thorsteinsdottir U, Ruggeri M, Tosato S, Franke B, Strengman E, Kiemeney LA, Genetic R, Outcome in P, Melle I, Djurovic S, Abramova L, Kaleda V, Sanjuan J, de Frutos R, Bramon E, Vassos E, Fraser G, Ettinger U, Picchioni M, Walker N, Toulopoulou T, Need AC, Ge D, Yoon JL, Shianna KV, Freimer NB, Cantor RM, Murray R, Kong A, Golimbet V, Carracedo A, Arango C, Costas J, Jonsson EG, Terenius L, Agartz I, Petursson H, Nothen MM, Rietschel M, Matthews PM, Muglia P, Peltonen L, St Clair D, Goldstein DB, Stefansson K, Collier DA (2009) Common variants conferring risk of schizophrenia. Nature 460: 744-7. doi: 10.1038 /nature08186

Steinberg S, de Jong S, Irish Schizophrenia Genomics C, Andreassen OA, Werge T, Borglum AD, Mors O, Mortensen PB, Gustafsson O, Costas J, Pietilainen OP, Demontis D, Papiol S, Huttenlocher J, Mattheisen M, Breuer R, Vassos E, Giegling I, Fraser G, Walker N, Tuulio-Henriksson A, Suvisaari J, Lonnqvist J, Paunio T, Agartz I, Melle I, Djurovic S, Strengman E, Group, Jurgens G, Glenthoj B, Terenius L, Hougaard DM, Orntoft T, Wiuf C, Didriksen M, Hollegaard MV, Nordentoft M, van Winkel R, Kenis G, Abramova L, Kaleda V, Arrojo M, Sanjuan J, Arango C, Sperling S, Rossner M, Ribolsi M, Magni V, Siracusano A, Christiansen C, Kiemeney LA, Veldink J, van den Berg $L$, Ingason A, Muglia $P$, Murray $R$, Nothen MM, Sigurdsson $E$, Petursson $H$, Thorsteinsdottir U, Kong A, Rubino IA, De Hert M, Rethelyi JM, Bitter I, Jonsson EG, Golimbet V, Carracedo A, Ehrenreich H, Craddock N, Owen MJ, O'Donovan MC, Wellcome Trust Case Control C, Ruggeri M, Tosato S, Peltonen L, Ophoff RA, Collier DA, St Clair D, Rietschel M, Cichon S, Stefansson H, Rujescu D, Stefansson K (2011) Common variants at VRK2 and TCF4 conferring risk of schizophrenia. Hum Mol Genet 20: 4076-81. doi: 10.1093/hmg/ddr325

Stuart T, Butler A, Hoffman P, Hafemeister C, Papalexi E, Mauck WM, 3rd, Hao Y, Stoeckius M, Smibert P, Satija R (2019) Comprehensive Integration of Single-Cell Data. Cell 177: 1888-1902 e21. doi: 10.1016/j.cell.2019.05.031

Sun CP, Sun D, Luan ZL, Dai X, Bie X, Ming WH, Sun XW, Huo XX, Lu TL, Zhang D (2020) Association of SOX11 Polymorphisms in distal 3'UTR with Susceptibility for Schizophrenia. J Clin Lab Anal: e23306. doi: 10.1002/jcla.23306

Tomasch J (1954) Size, distribution, and number of fibres in the human corpus callosum. Anat Rec 119: 119-35. doi: 10.1002/ar.1091190109

Turan S, Boerstler T, Kavyanifar A, Loskarn S, Reis A, Winner B, Lie DC (2019) A novel human stem cell model for Coffin-Siris Syndrome like syndrome reveals the importance of SOX11 dosage for neuronal differentiation and survival. Hum Mol Genet. doi: 10.1093/hmg/ddz089

Tzeng M, du Souich C, Cheung HW, Boerkoel CF (2014) Coffin-Siris syndrome: phenotypic evolution of a novel SMARCA4 mutation. Am J Med Genet A 164A: 180814. doi: 10.1002/ajmg.a.36533 
941 Wilson BJ, Harada R, LeDuy L, Hollenberg MD, Nepveu A (2009) CUX1 transcription

942 factor is a downstream effector of the proteinase-activated receptor 2 (PAR2). J Biol

943 Chem 284: 36-45. doi: 10.1074/jbc.M803808200

944 Zweier C, Peippo MM, Hoyer J, Sousa S, Bottani A, Clayton-Smith J, Reardon W, 945 Saraiva J, Cabral A, Gohring I, Devriendt K, de Ravel T, Bijlsma EK, Hennekam RC,

946 Orrico A, Cohen M, Dreweke A, Reis A, Nurnberg P, Rauch A (2007) 947 Haploinsufficiency of TCF4 causes syndromal mental retardation with intermittent 948 hyperventilation (Pitt-Hopkins syndrome). Am J Hum Genet 80: 994-1001. doi: $949 \quad 10.1086 / 515583$

950

951

952

953

954

955

956 
bioRxiv preprint doi: https://doi.org/10.1101/2020.06.16.156083; this version posted June 19, 2020. The copyright holder for this preprint (which was not certified by peer review) is the author/funder, who has granted bioRxiv a license to display the preprint in perpetuity. It is made available under aCC-BY 4.0 International license.
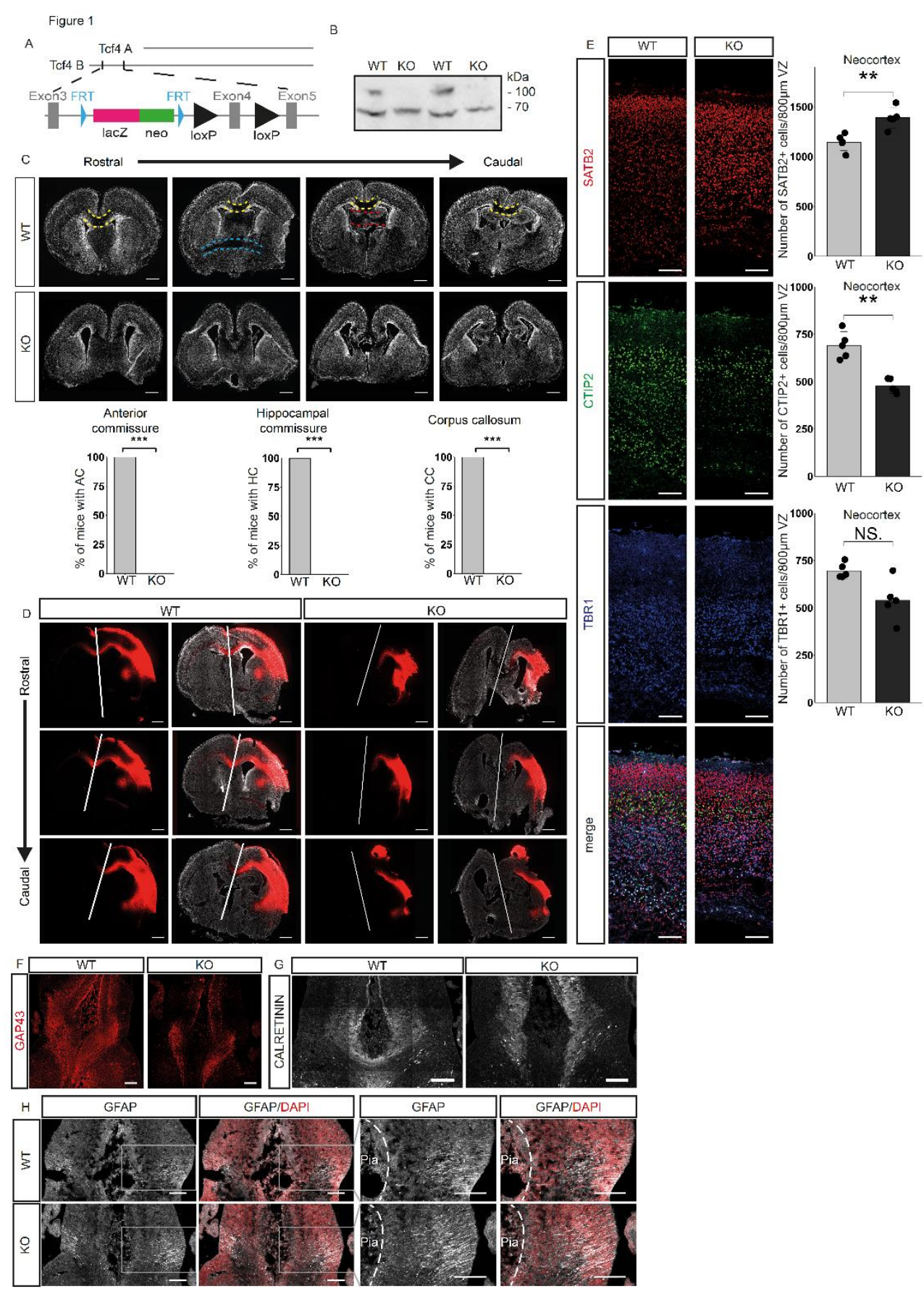

\section{Figure 1. Loss of Tcf4 disrupts cortex development, especially commissure formation}

A Schematic representation of the two main Tcf4 isoform and the 'knockout-first' conditional allele.

B Western Blot analysis of neocortical extracts from E18.5 WT or Tcf4KO mice using anti-TCF-4 antibody. The blot presented is cropped. The longest isoform of TCF-4 is missing in the KO samples $(n=3)$.

C Representative overview images (DAPI) of brain sections at PO showing the loss of the three commissure systems in Tcf4KO mice. Yellow dotted lines indicate the $\mathrm{CC}$ crossing the midline. Blue dotted lines indicate the $\mathrm{AC}$ and red dotted lines the $\mathrm{HC}$. Quantification of animals showing a commissural system is presented below $(n=8)$. Scale bar, $500 \mu m$. Statistical significance was determined by two-tailed Mann-Whitney-U test $\left({ }^{*}, \mathrm{P} \leq 0.05 ;{ }^{* *}, \mathrm{P} \leq 0.01,{ }^{* *}, \mathrm{P} \leq 0.001\right)$

D Representative images of lipophilic tracer (red) treated brains at P0 without or with DAPI staining (white). White lines indicate the midline. Note that only in WT animals, lipophilic tracer signal can be detected in the contralateral hemispheres to the treatment $(n=3)$. Scale bar, $500 \mu \mathrm{m}$.

E Representative images of the neuronal markers SATB2 (upper layers), CTIP2 (layer V) and TBR1 (layer 6) and the quantification of the total cell number expressing these markers per $800 \mu \mathrm{m}$ ventricular zone (VZ). A significant increase in SATB2+ neurons is observable as is a significant decrease in CTIP2+ cells. Scale bar $100 \mu \mathrm{m}$. Data is presented as mean \pm SD; $(n=5)$. Statistical significance was determined by two-tailed Mann-Whitney-U test $\left({ }^{*}, P \leq 0.05 ;{ }^{* *}, P \leq 0.01,{ }^{* *}, P \leq 0.001\right)$.

F Representative images for GAP43 at the midline of E16.5 mouse brains. Scale bar, $100 \mu \mathrm{m},(\mathrm{n}=3)$.

G Representative images of CALRETININ expression at the midline at E16.5. Scale bar, $100 \mu \mathrm{m},(n=3)$.

H Representative images of GFAP stainings at E16.5. Pictures on the right side are magnifications of the marked area. Dotted lines represent the pial surface. Scale bar, $100 \mu \mathrm{m},(n=3)$. 
bioRxiv preprint doi: https://doi.org/10.1101/2020.06.16.156083; this version posted June 19, 2020. The copyright holder for this preprint (which was not certified by peer review) is the author/funder, who has granted bioRxiv a license to display the preprint in perpetuity. It is made available under aCC-BY 4.0 International license.

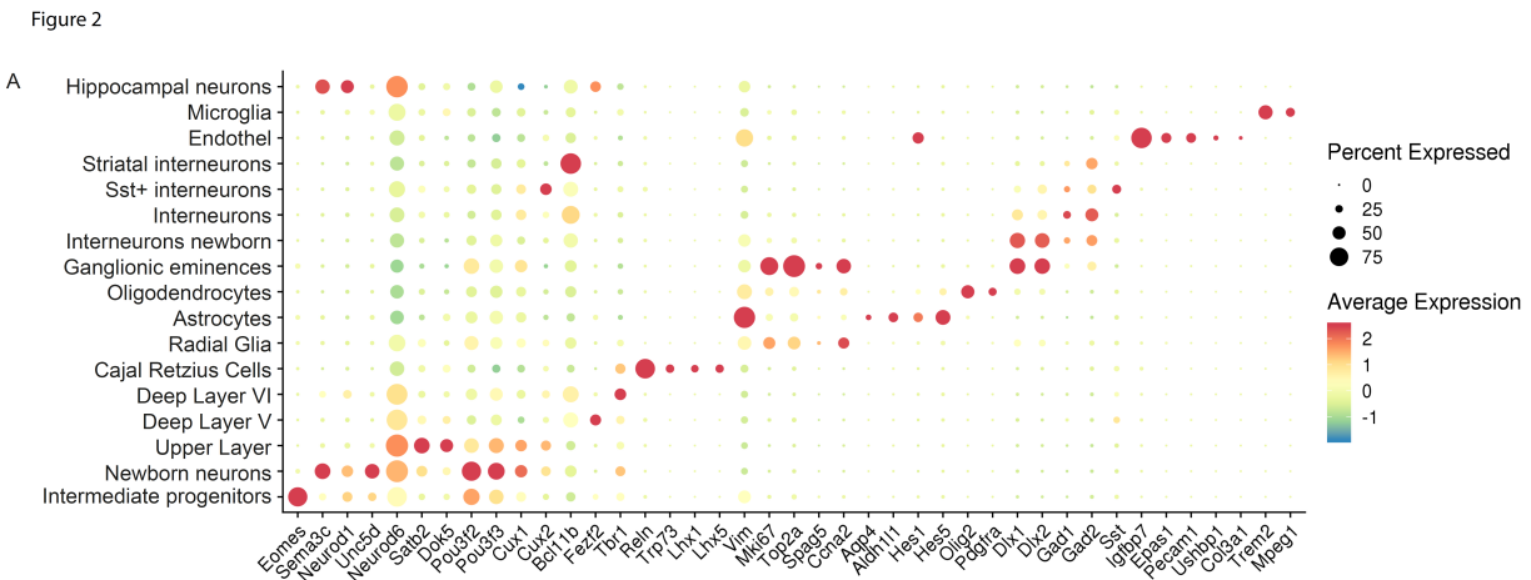

B
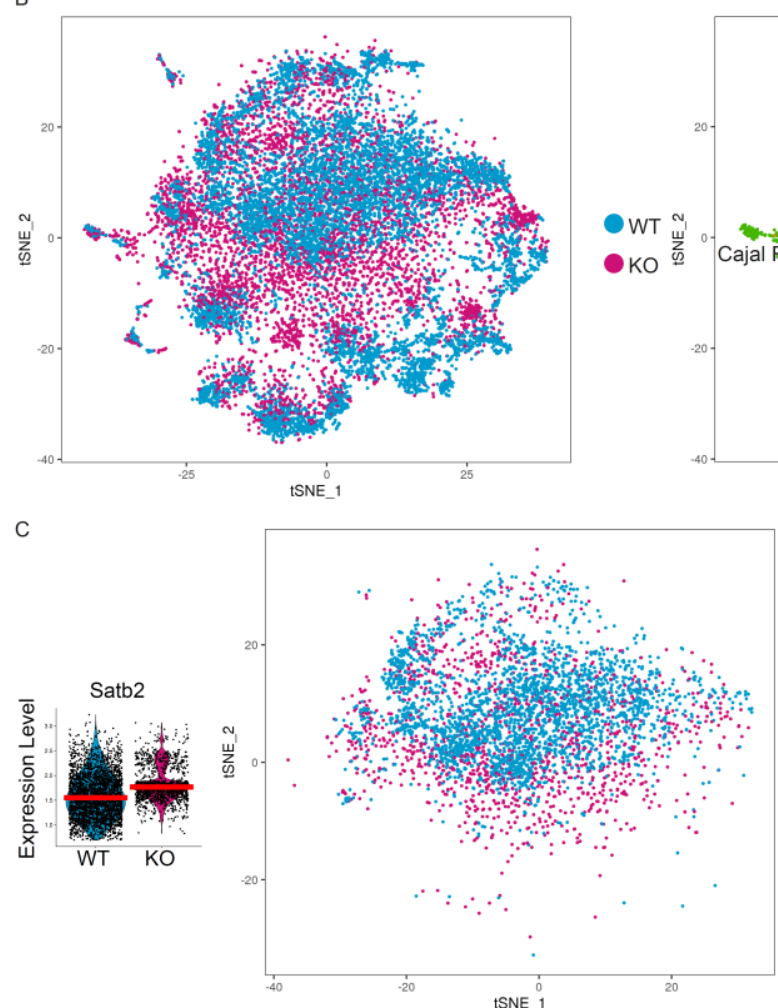

Features

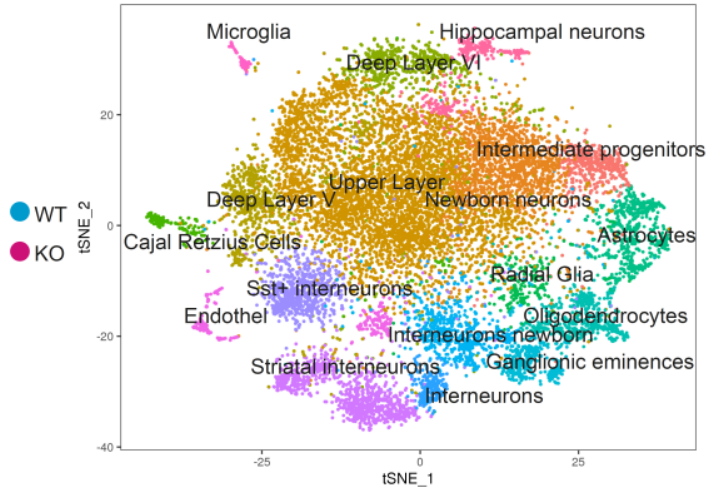

Intermediate progenitors

Newborn neurons

Upper Layer

Deep Layer VI

Cajal Retzius Cells

Radial Glia

Astrocytes

Oligodendrocytes

Ganglionic eminences

Interneurons newborn

Interneurons

Sst+ interneurons

Striatal interneurons

Endothel

Microglia

Hippocampal neurons

E

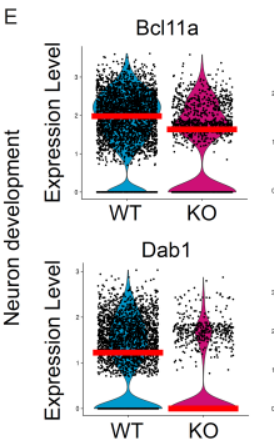

Cux1
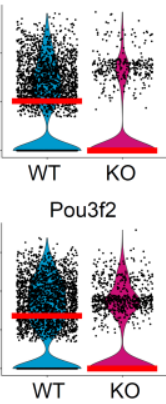

Dok5

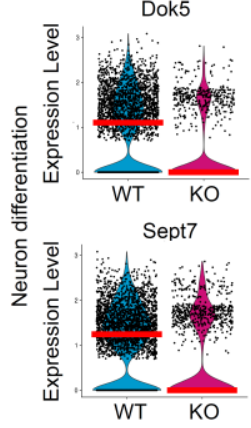

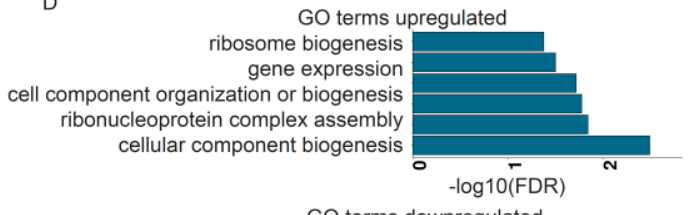

GO terms downregulated

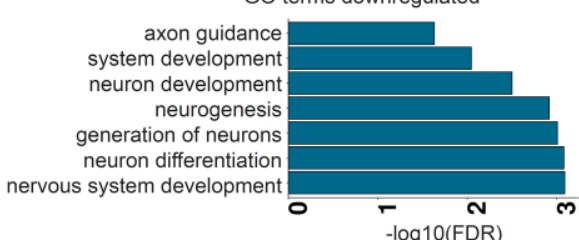

Rab3a

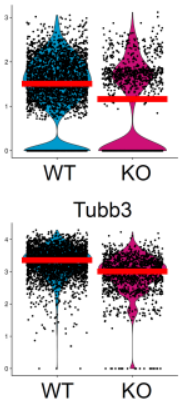

Nrp1

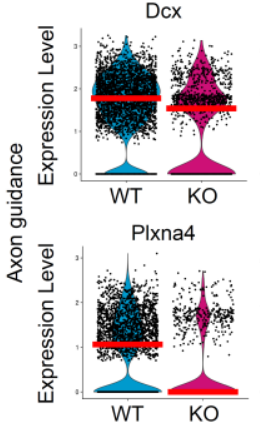

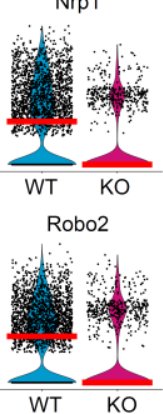

Figure 2. Single-cell RNA Sequencing of E18.5 neocortices from WT and Tcf4KO mice

1012 A Dot-Plot of cell clusters (y-axis) and marker used to assign the cell type (x-axis).

1013 B tSNE-Plot coloured by genotype (left) and cluster identity (right).

C tSNE-Plot of Satb2 expressing glutamatergic cells used for further analysis. Violin Plot of Satb2 expression in the Satb2 cluster. The red line depicts the median.

D GO terms associated with up- and downregulated genes in SATB2 expressing glutamatergic cells. GO terms for neurogenesis, neuronal differentiation and axonogenesis were downregulated in the Tcf4KO cells.

1018 E Violin Plot of differentially expressed genes in the Satb2 cluster that are associated to neuron development/differentiation and

1019 axon guidance. The red line depicts the median. 
bioRxiv preprint doi: https://doi.org/10.1101/2020.06.16.156083; this version posted June 19, 2020. The copyright holder for this preprint (which was not certified by peer review) is the author/funder, who has granted bioRxiv a license to display the preprint in perpetuity. It is made available under aCC-BY 4.0 International license.
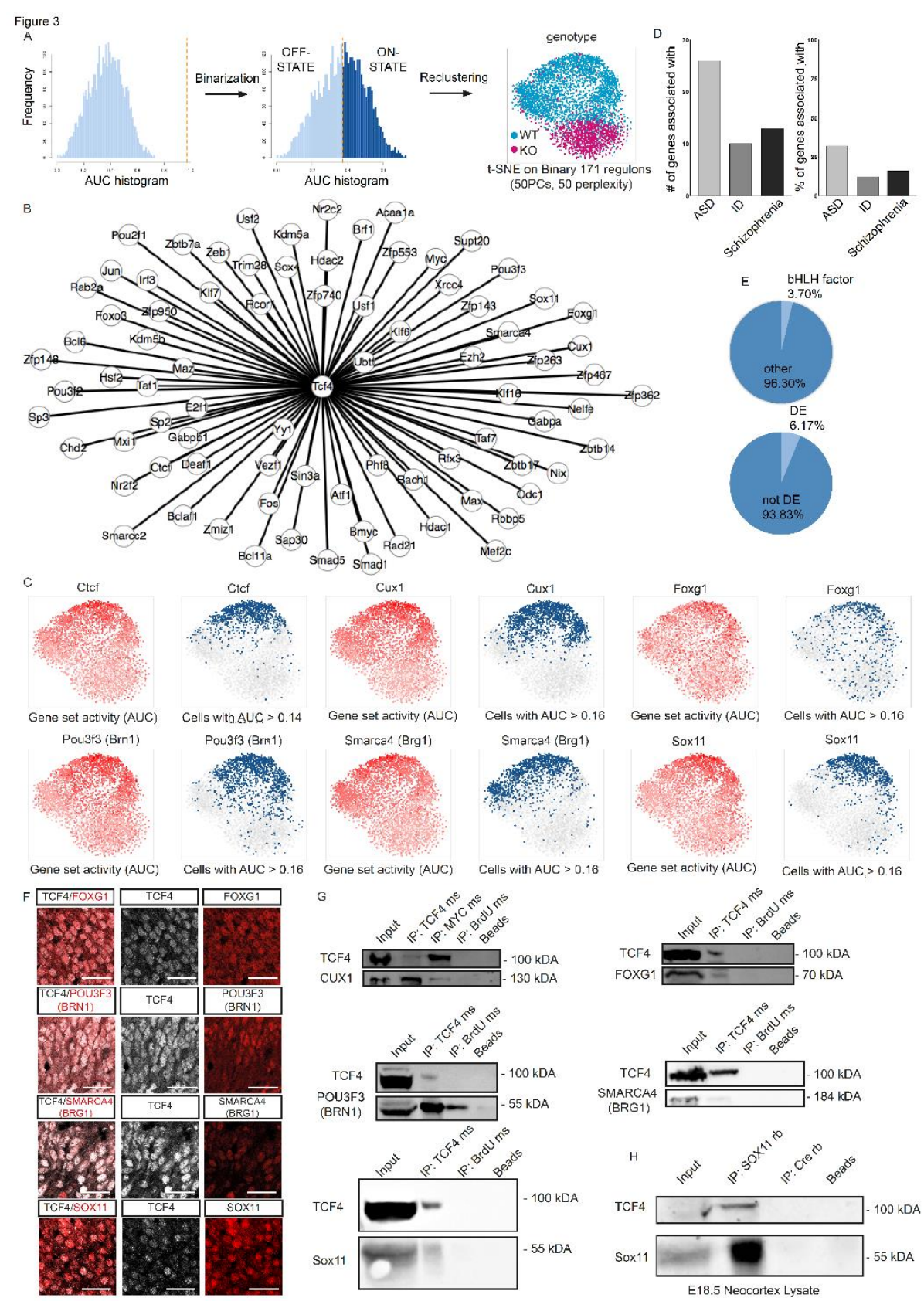

Figure 3. Gene regulatory network analysis of SATB2 expressing cells

A Scheme of the workflow used to recluster cells after GRN analysis and resulting tSNE-Plot of the Satb2 cluster. Regulons are binarized and reclustered accordingly. WT and KO cells segregated based on GRN activity with only minor overlap.

B Differentially active regulons of the Satb2 cluster that may be possible interactors of TCF-4.

C tSNE-Plots showing the regulon activity of Ctcf, Cux1, Foxg1, Pou3f3 (also known as Brn1), Smarca4 (also known as Brg1) and Sox11 in a continuous scale (left, red) or binarized (right, blue). The regulons are preferentially active in the WT cells with only a small number of $\mathrm{KO}$ cells in the ON-State.

D Number and percentage of regulators associated with autism spectrum disorders (ASD), intellectual disability (ID) and schizophrenia in the Satb2 cluster.

E Pie charts depicting the percentage of bHLH factors and differentially expressed regulators in the differentially active regulons. F Representative images of TCF-4 (white) and FOXG1, POU3F3 (BRN1), SMARCA4 (BRG1) and SOX11 (all in red) in E18.5 WT cortices. Note the expression in the same nuclei. Scale bar, $50 \mu \mathrm{m}$

D Co-immunoprecipitation assay using anti-TCF-4 antibody conducted with HEK cell extract after overexpression of TCF-4 and CUX1, FOXG1, POU3F3 (BRN1), SMARCA4 (BRG1) and SOX11 in HEK cells. Upper panels: detection with anti-TCF-4 antibody. Lower panels: detection with anti-MYC, anti-FOXG1, anti-BRN1, anti-BRG1 or anti-SOX11 antibody. The blots presented are cropped. All proteins were co-immunoprecipitated with TCF-4, but not with an isotype control for lgG or Agarose A Beads alone except for BRN-1 which was precipitated to a small amount by the isotope control lgG. We could also show that TCF-4 was co-immunoprecipitated with anti-Myc antibody (precipitation of Myc-tagged Cux1). The interactions were confirmed in three independent biological replicates, $(n=3)$.

E Co-immunoprecipitation assay conducted with E18.5 cortex lysates using anti-SOX11 antibody. Upper panel: detection with anti-TCF-4 antibody. Lower panel: detection with anti-SOX11 antibody. The blots presented are cropped. TCF-4 was coimmunoprecipitated with SOX11, but not with an isotype control for IgG and Agarose A Beads alone. The interaction was confirmed in three independent biological replicates $(n=3)$. 
bioRxiv preprint doi: https://doi.org/10.1101/2020.06.16.156083; this version posted June 19, 2020. The copyright holder for this preprint (which was not certified by peer review) is the author/funder, who has granted bioRxiv a license to display the preprint in perpetuity. It is made available under aCC-BY 4.0 International license.
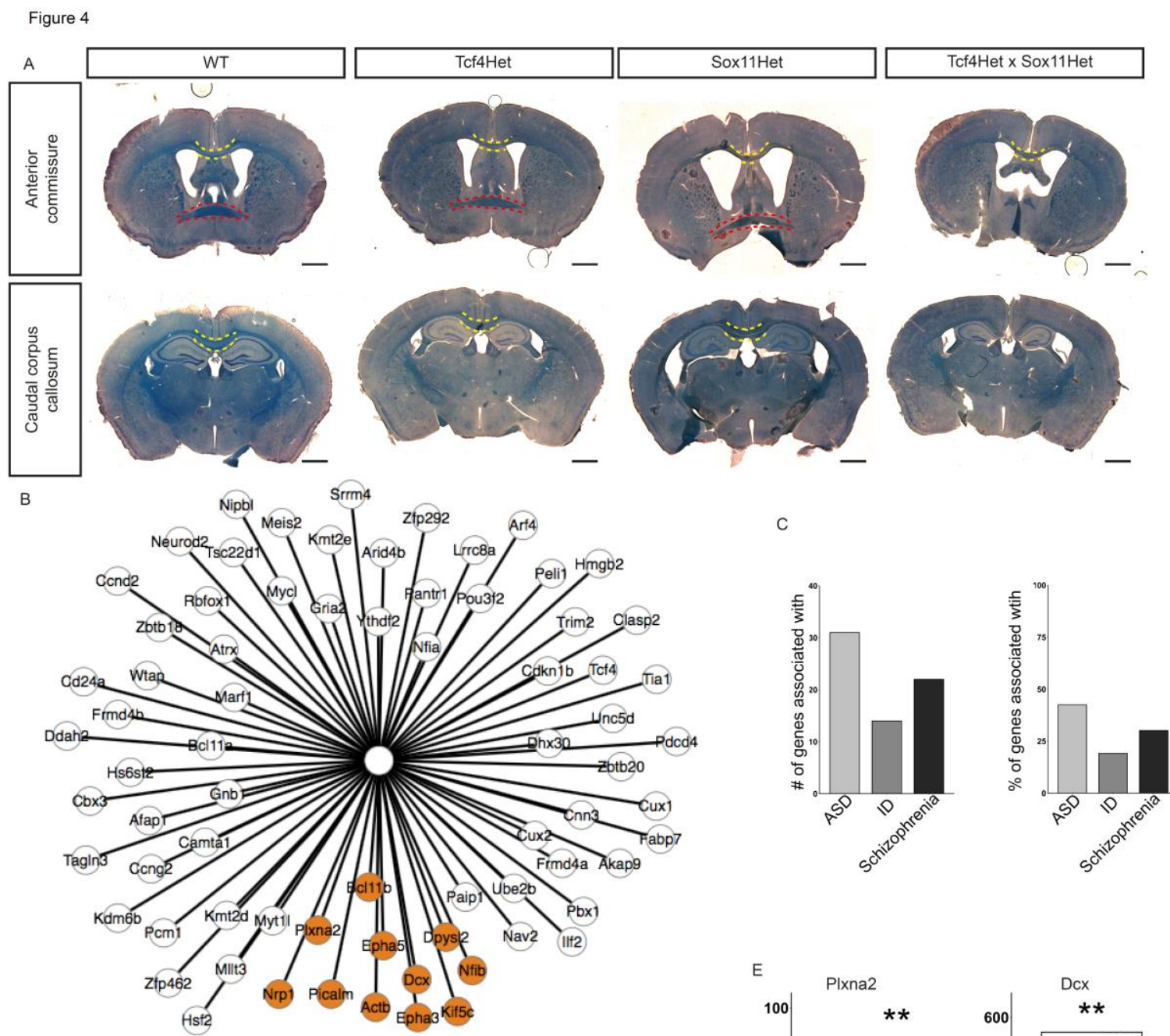

$\mathrm{D}$

GO terms associated to TCF-4 and SOX11 targets

cell morphogenesis involved in neuron differentiation

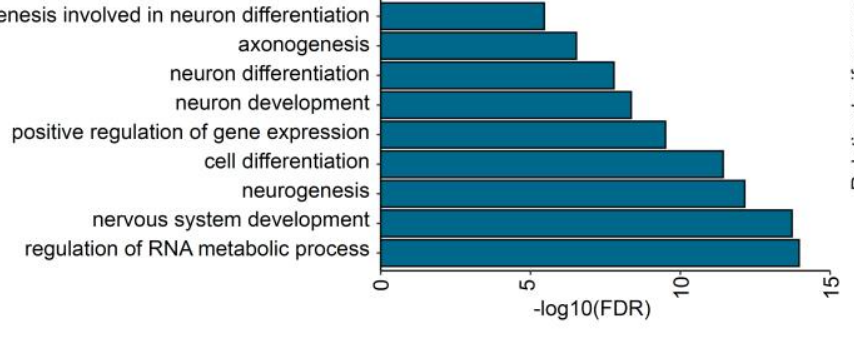

C
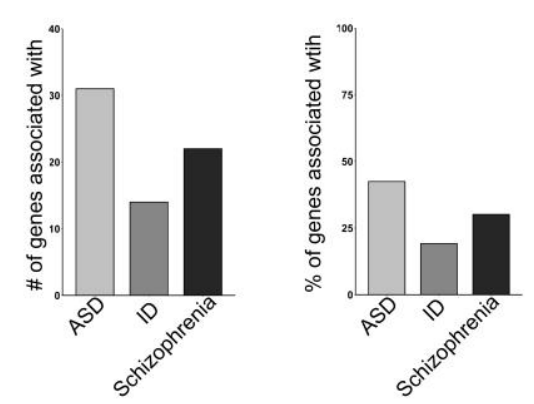

\section{Figure 4. TCF-4 and SOX11 act synergistically in corpus callosum formation}

1075

A Representative overview images of Luxol fast blue stainings at the position of the AC and the caudal body of the CC. Yellow dotted lines indicate the CC crossing the midline. Red dotted lines indicate the AC. In Tcf4 and Sox11 double haploinsufficient mice agenesis of the AC and agenesis of the splenium and caudal part of the body of the CC can be observed. Scale bar, 1000 $\mu \mathrm{m},(\mathrm{n}=5)$.

B Common targets of TCF-4 and SOX11 in the Satb2 cluster. Orange highlighted genes are associated with the GO term axonogenesis.

C Number and percentage of common targets of TCF-4 and SOX11 in the Satb2 cluster associated to autism spectrum disorders (ASD), intellectual disability (ID) and schizophrenia in the Satb2 cluster.

D Selection of GO terms associated with the common targets of TCF-4 and SOX11 in the Satb2 cluster. GO terms for neurogenesis, neuronal differentiation and axonogenesis were enriched.

E Relative luciferase reporter gene activity under the control of the regulatory regions from the Plxna2 (C) and Dcx (D) in transiently transfected HEK cells co-expressing TCF-4, SOX 11 and a combination of the two $(n=3$, presented as fold induction $\pm \mathrm{SD}$, transfection with empty CAG-GFP vector was set to 1 for each regulatory region). Statistical significance was determined by a two-tailed student's t-test. $\left({ }^{*}, \mathrm{P} \leq 0.05 ;{ }^{* *}, \mathrm{P} \leq 0.01,{ }^{* * *}, \mathrm{P} \leq 0.001\right)$ 


\section{Supplement}

1091 Supplemental Dataset 1. Differential expressed genes in the Satb2 cluster and 1092 GO term analysis. Related to Figure 2.

1093 Supplemental Dataset 2. Differential expressed genes in the limited Satb2 1094 cluster and GO term analysis. Related to Figure 2.

1095 Supplemental Dataset 3. Differential active regulons in the Satb2 cluster. 1096 Related to Figure 3.

1097 Supplemental Dataset 4. Differential active regulons in the limited Satb2 1098 cluster. Related to Figure 3.

1099 Supplemental Dataset 5. Overlap of differential expressed genes and the 1100 predicted Sox11 regulon in the Satb2 cluster and GO term analysis. Related to 1101 Figure 4. 